\title{
Modeling and Simulation of Incident Management for Homeland Security Applications
}

Charles McLean

Y. Tina Lee

Dr. Sanjay Jain

Dr. Charles Hutchings

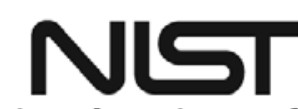




\title{
Modeling and Simulation of Incident Management for Homeland Security Applications
}

\author{
Charles McLean \\ Y. Tina Lee \\ Manufacturing Systems Integration Division \\ Engineering Laboratory \\ Dr. Sanjay Jain \\ George Washington University \\ Dr. Charles Hutchings \\ U.S. Department of Homeland Security
}

September 2011

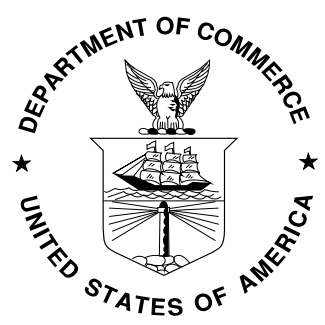

U.S. Department of Commerce Rebecca M. Blank, Acting Secretary

National Institute of Standards and Technology Patrick D. Gallagher, Under Secretary for Standards and Technology and Director 


\section{ACKNOWLEDGMENTS}

The U.S. Department of Homeland Security Science and Technology Directorate sponsored the production of this material under Interagency Agreements HSHQDC-09-X-00009 and HSHQDC-09-X00357 with the National Institute of Standards and Technology (NIST). The work described was funded by the United States Government and is not subject to copyright.

\section{DISCLAIMERS}

The findings expressed or implied in this report do not necessarily reflect the official view or policy of the U.S. Department of Homeland Security, U.S. Department of Commerce, or the United States Government.

Some software products may have been identified in context in this report. This does not imply a recommendation or endorsement of the software products by the authors or NIST, nor does it imply that such software products are necessarily the best available for the purpose.

Comments or questions about this report may be e-mailed to: simresponse@cme.nist.gov. 


\section{Contents}

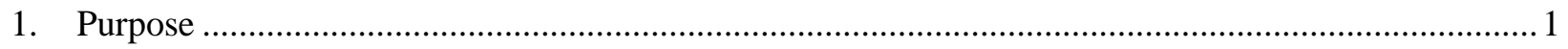

2. Introduction to Incident Management and Associated DHS Guidance ............................................ 2

3. Perspectives on Methodologies, Models, and Simulations............................................................ 5

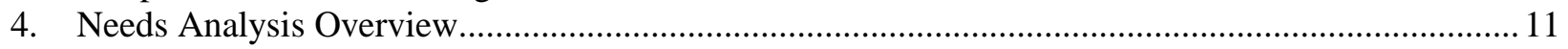

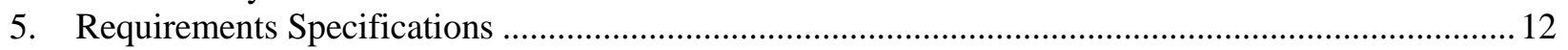

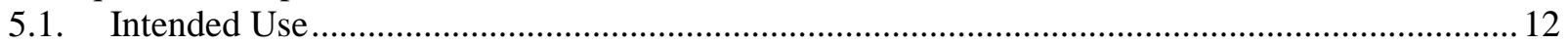

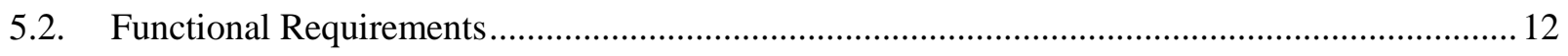

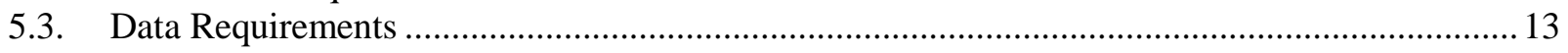

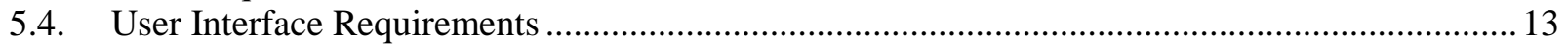

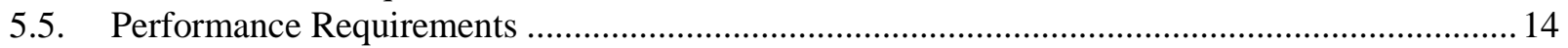

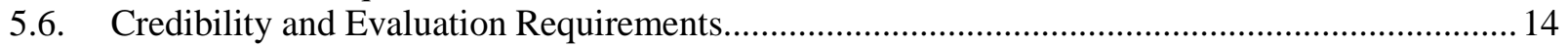

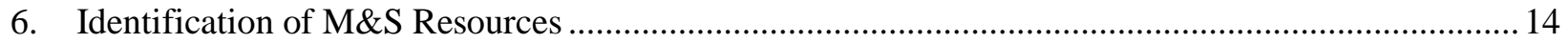

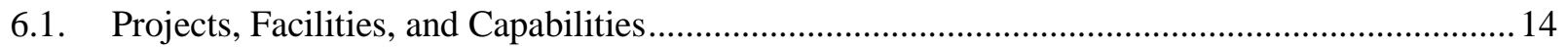

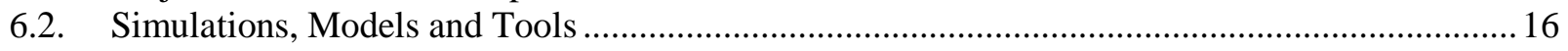

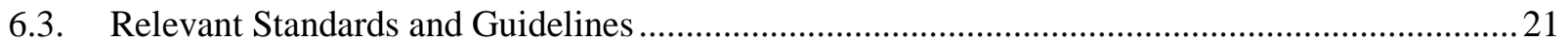

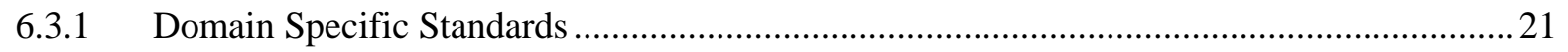

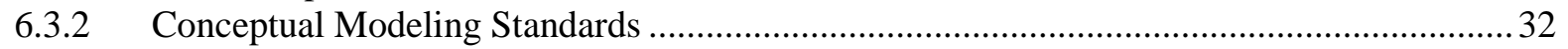

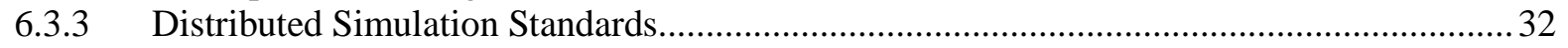

6.3.4 Selected Geographic Information System (GIS) Standards ............................................... 34

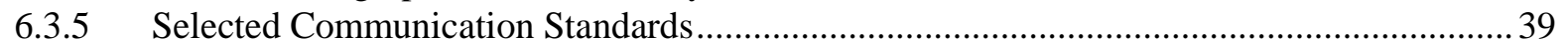

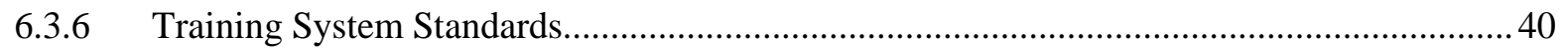

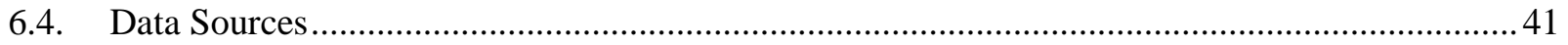

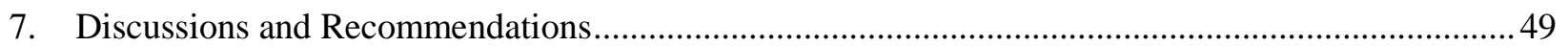

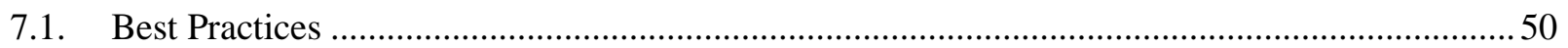

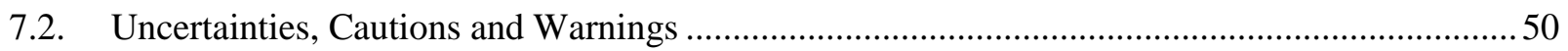

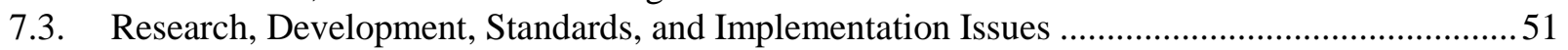

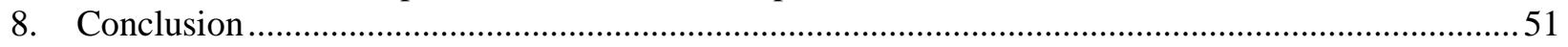

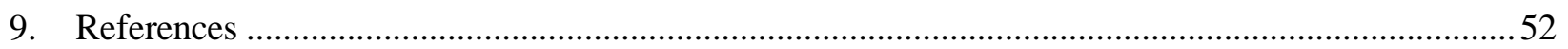


This page left blank intentionally. 


\section{Purpose}

Incident management models and simulations may be used to support analysis, planning, and training needs pertaining to terrorist attacks, national security events, natural and man-made disasters. Simulation models may be used to understand incident management systems, interdependencies with other systems, their vulnerabilities, and the impact of emergency incidents on the population and responder community. Incident management models and simulations will be used to support training exercises, performance measurement, conceptual design, impact evaluation, response planning, analysis, acquisition, conceptualizing and evaluating new systems, vulnerability analysis, economic impact, and determining interdependencies between incident management and other infrastructure systems.

The goal of this document is to capture the current knowledge and information resources that can serve as a common baseline for researchers and developers of incident management models and simulations for homeland security applications. This initial version of the document attempts to assemble relevant, publicly available information from a number of sources within U.S. Department of Homeland Security (DHS) and the modeling and simulation (M\&S) communities.

This document is intended to help initiate the discussion of the current leading research, development, standards, and implementation issues within the incident management M\&S community, as it relates to homeland security. The document will be updated based on the input of domain experts across government, research, and commercial organizations. These experts will be invited to join together in a workshop to review and extend this document for its final publication. The workshop will focus on simulation and modeling activities and needs that support analysis, planning, and training for the healthcare systems as well as the integration of M\&S applications with each other and other data systems. Issues to be addressed within the scope of this workshop include the establishment of consensus on:

- identification of subject matter experts

- definition of customer and user needs

- system requirements specifications

- recommended/approved modeling techniques and approaches

- identification of data sources, reference data sets, formats, and standards

- identification of appropriate model evaluation and accreditation practices

The workshop will also help identify the current leading research, development, standards, and implementation issues. Such analysis by the workshop participants may be found to be relevant by future efforts for developing standards, conducting research and development, and enhancing implementation policies and procedures for homeland security applications of M\&S to improve the protection of critical infrastructure systems. A preliminary workshop that addressed modeling and simulation of healthcare systems was held in 2008, see [NIST 2010b] for further information.

This document provides a compendium of information that has been assembled that is relevant to incident management M\&S. Incident management is introduced in Section 2. Section 3 provides a general background on methodologies, models, and simulations. An initial set of high level user and customer needs for M\&S applications in the incident management domain is presented in Section 4. Section 5 translates the high level needs to a representative set of M\&S system requirements (a more detailed specification is currently under development in a related effort). The existing M\&S resources and capabilities such as projects, tools, standards, and data sets that have been developed over the years to meet the needs and requirements are identified in Section 6. Section 7 presents a discussion of issues, concerns, and recommendations for advancing $M \& S$ for critical infrastructure protection emanating from 
a comparison of current resources and capabilities with the needs and requirements. Section 8 concludes the document while section 9 provides list of references used.

Three additional documents have been prepared as a part of this effort. The other documents address M\&S for critical infrastructure and key resources (CIKR), healthcare systems, and releases of hazardous materials. To minimize redundancy between the documents, each document focuses on the M\&S techniques that are most significant to the sectors mission and objectives. The CIKR document emphasizes modeling and simulation supporting analysis of systems (e.g., vulnerability, security), whereas the incident management document focuses more on training and exercises. The healthcare systems document addresses M\&S for analysis, training, and exercises, but at a more detailed level than the previous two documents. The hazardous material releases document focuses on the more physical aspects of M\&S associated with explosions, fires, plumes, and the flow of hazardous materials in building ventilation systems, bodies of water, and the soil. The authors recognize that each of the domains may employ all of the M\&S techniques that have been identified in the other documents, but typically to a lesser extent.

The authors welcome identification of omissions as well as suggestions for improvements. Please contact the authors directly or submit comments or questions by e-mail to simresponse@cme.nist.gov.

\section{Introduction to Incident Management and Associated DHS Guidance}

The National Incident Management System (NIMS) [DHS 2008] and National Response Framework (NRF) [DHS 2008] provide the relevant guidance for the incident management domain. Incidents and their management are defined in NIMS as below.

"Incident: An occurrence, natural or manmade, that requires a response to protect life or property. Incidents can, for example, include major disasters, emergencies, terrorist attacks, terrorist threats, civil unrest, wildland and urban fires, floods, hazardous materials spills, nuclear accidents, aircraft accidents, earthquakes, hurricanes, tornadoes, tropical storms, tsunamis, war-related disasters, public health and medical emergencies, and other occurrences requiring an emergency response.”

“Incident Management: The broad spectrum of activities and organizations providing effective and efficient operations, coordination, and support applied at all levels of government, utilizing both governmental and nongovernmental resources to plan for, respond to, and recover from an incident, regardless of cause, size, or complexity.”

From the definitions it is clear that incident management has a broad scope since it involves a wide range of activities, includes a large number of organizations, in response to an even wider range of emergency threats and occurrences. DHS has developed a set of documents to organize and manage the complexity of the broad scope. The two major documents are the NIMS and NRF mentioned above, each with a set of associated documents and components. Homeland Security Presidential Directive-5 (HSPD-5) [DHS 2003], called upon the Secretary of Homeland Security to develop a national incident management system (NIMS). The NIMS provides a systematic approach to guide all involved organizations through the entire life-cycle of preventing, protecting against, responding to, recovering from, and mitigating the effects of incidents while the NRF focuses on preparing for and providing a unified national response to incidents. NIMS, together with NRF and other documents, provides the structure needed to coordinate, integrate, and synchronize activities derived from various relevant statutes, national strategies, and Presidential directives to create a unified national approach to implementing the incident management mission (see Figure 1). 
NIMS has five major components: Preparedness, Communications \& Information Management, Resource Management, Command \& Management, and Ongoing Management \& Maintenance. The ongoing management \& maintenance component specifically refers to M\&S. The component has two subsections: National Integration Center (NIC) and Supporting Technologies. NIC's role includes developing M\&S capabilities for training and exercise programs and maintaining a repository of best practices manuals, models, and recommendations.

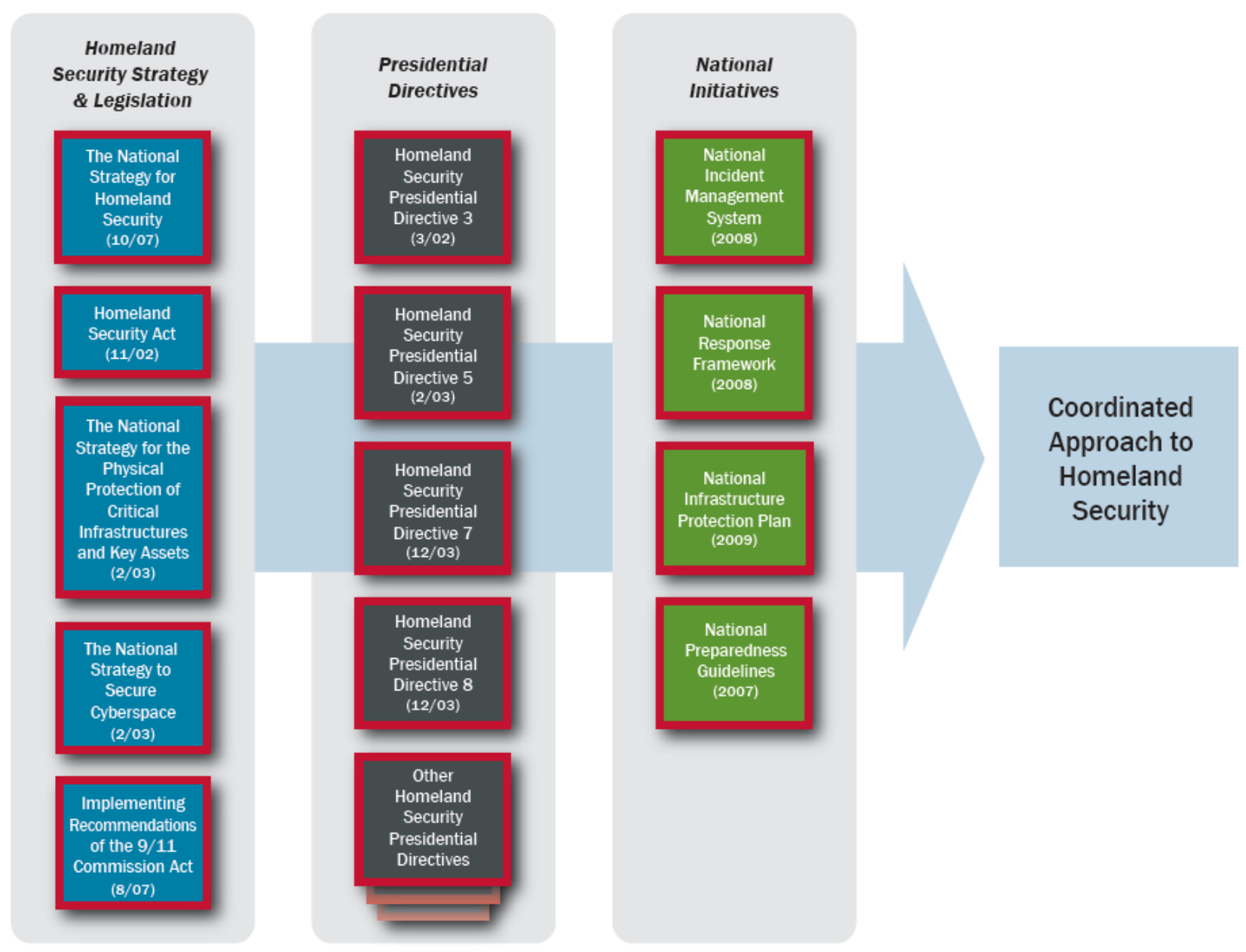

Figure 1: National Framework for Homeland Security (from [DHS 2009a])

A major sub-component of the Command and Management component of NIMS is the Incident Command System (ICS). The Incident Command System is "a standardized, on-scene, all-hazards incident management approach that:

- Allows for the integration of facilities, equipment, personnel, procedures, and communications operating within a common organizational structure.

- Enables a coordinated response among various jurisdictions and functional agencies, both public and private.

- Establishes common processes for planning and managing resources.” [FEMA 2010]

The ICS calls for use of technical specialists in planning and other parts of the recommended incident command organizational structure. The technical specialists' roles include providing information that 
may support tactical decisions on an incident. Numerical modelers are specifically identified as a category of technical specialists. M\&S experts may thus be included as technical specialists in ICS to provide support for tactical decisions.

The NRF defines the roles and responsibilities, response actions and organizations, and emphasizes planning as a critical element of the response. It introduces national planning scenarios to be used as a critical element for preparedness. The 15 national planning scenarios [FEMA 2009] may be used to help focus efforts to prepare for natural disasters, terrorist attacks, and other serious incidents. The national planning scenarios are Improvised Nuclear Device; Aerosol Anthrax; Pandemic Influenza; Plague; Blister Agent; Toxic Industrial Chemicals; Nerve Agent; Chlorine Tank Explosion; Major Earthquake; Major Hurricane; Radiological Dispersal Device; Improvised Explosive Device; Food Contamination; Foreign Animal Disease; and Cyber Attack.

- Improvised Nuclear Device scenario is based upon a 10-kiloton nuclear detonation in a large metropolitan area.

- Aerosol Anthrax scenario is an aerosol attack spread by a truck in a city.

- Pandemic Influenza scenario involves the outbreak of influenza for which there has not been an effective preplanned response.

- Plague scenario is a pneumonic plague that strikes three areas of a major metropolitan city.

- Blister Agent scenario involves a light aircraft spraying chemical blister agents into a packed college football stadium.

- Toxic Industrial Chemicals scenario is an attack where a group of terrorists land helicopters at a petroleum refinery, start fires with rocket-propelled grenades and improvised explosive devices that result in a toxic chemical release.

- Nerve Agent scenario involves the release of Sarin vapor into the ventilation systems of three commercial office buildings in a busy metropolitan area.

- Chlorine Tank Explosion scenario involves an explosion at an industrial facility and the release of a large quantity of chlorine gas.

- Major Earthquake scenario is a 7.2 magnitude quake that occurs along a fault zone in a major city.

- Major Hurricane scenario is a Category 5 hurricane that hits a major metropolitan area.

- Radiological Dispersal Device (RDD) scenario involves separate Cesium Chloride bomb attacks on three regionally close, moderate-to-large cities.

- Improvised Explosive Device (IED) scenario involves IED bombings inside a sports arena, at a parking facility near an entertainment complex, and suicide bomber attacks in an underground public transportation concourse.

- Food Contamination scenario involves the distribution of anthrax-contaminated ground beef and orange juice to different states and cities.

- Foreign Animal Disease scenario is a coordinated bio-terrorism attack that infects farm animals with foot and mouth disease at several large livestock operations.

- Cyber Attack is a computer attack that is directed at several parts of the national financial infrastructure over the course of several weeks.

M\&S tools and applications should, wherever possible, support the fifteen national planning scenarios defined by DHS. It is likely that incident management systems will play a significant role in most of the national planning scenarios, with the possible exception of the cyber attack scenario.

The NRF defines 15 emergency support functions (ESFs) that can be used to coordinate response in functions such as transportation, communications, firefighting, mass care, housing, public health and medical services, search and rescue, and energy. Some of the annexes specifically call for use of M\&S. ESF\#8 - Public Health and Emergency Services calls for use of Interagency Modeling and Atmospheric 
Assessment Center (IMAAC) to provide predictions using M\&S of hazards associated with atmospheric releases for use in emergency response. ESF\#10- Oil and Hazardous Material also calls for use of IMAAC for such predictions and for use of M\&S for oil spill trajectory analysis and calculation of pipeline oil discharge volumes. The ESF\#12- Energy recommends use of M\&S for modeling impact of disruptions to the energy sector on economy, and on other critical infrastructure and key resources. ESF\#13 - Public Safety and Security calls for use of modeling and forecasting for crowd size, impact of weather, and other conditions to analyze potential factors that may affect resource allocations. It also notes the possibility of requesting National Aeronautics and Space Administration (NASA) capabilities for geospatial modeling and decision support if needed.

\section{Perspectives on Methodologies, Models, and Simulations}

Concise Oxford Dictionary of Current English, 1996, defines Methodology as "a body of methods used in a particular activity.” Methodology is principles of method, and such principles can be used to study and inform problem solving and decision-making. [Checkland 2000] describes a useful model linking methodology and the user of a methodology to problem solving:

'A problem-solving situation with three elements:

- A user of methodology (this assumes that the user is familiar with the methodology)

- Methodology as documented

- Situation as perceived by the user

Relationship and interactions between the three elements are encapsulated in the LUMAS model (Learning, User of methodology, Methodology formally described, Actual approach adopted, and real world problem Situation) shown in figure 2. A simple example narrative for the diagram may be: A user, $U$, appreciating a methodology, $M$, as a coherent set of principles and perceiving a problem situation, S, asks, “what can I do?" The User then tailors from $M$ a specific approach, A, judged to be appropriate for $S$, and uses it in an attempt to improve the situation. This generates learning, $L$, which may change the user, $U$ or the methodology, $M$.

A methodology is, then, a logical framework that not only brings forth learning for an individual, but does so in a consistent and systemic manner so learnings can be shared and passed on.'

Another perspective on methodology comes from the International Council on Systems Engineering (INCOSE) where methodology is defined as "a collection of related processes, methods and tools" [INCOSE 2008]. This is based on definitions from [Martin 1996]:

'Methodology can be differentiated from other related concepts using the following definitions from [Martin 1996]:

- A Process $(P)$ is a logical sequence of tasks performed to achieve a particular objective. A process defines "WHAT" is to be done, without specifying "HOW" each task is performed. The structure of a process provides several levels of aggregation to allow analysis and definition to be done at various levels of detail to support different decision-making needs.

- A Method (M) consists of techniques for performing a task, in other words, it defines the "HOW" of each task. (In this context, the words: "method," "technique," "practice," and "procedure" are often used interchangeably.) At any level, process tasks are performed using methods. However, each method is also a process itself, with a sequence of tasks to be performed for that particular method. In other words, the "HOW" at one level of abstraction becomes the "WHAT" at the next lower level. 


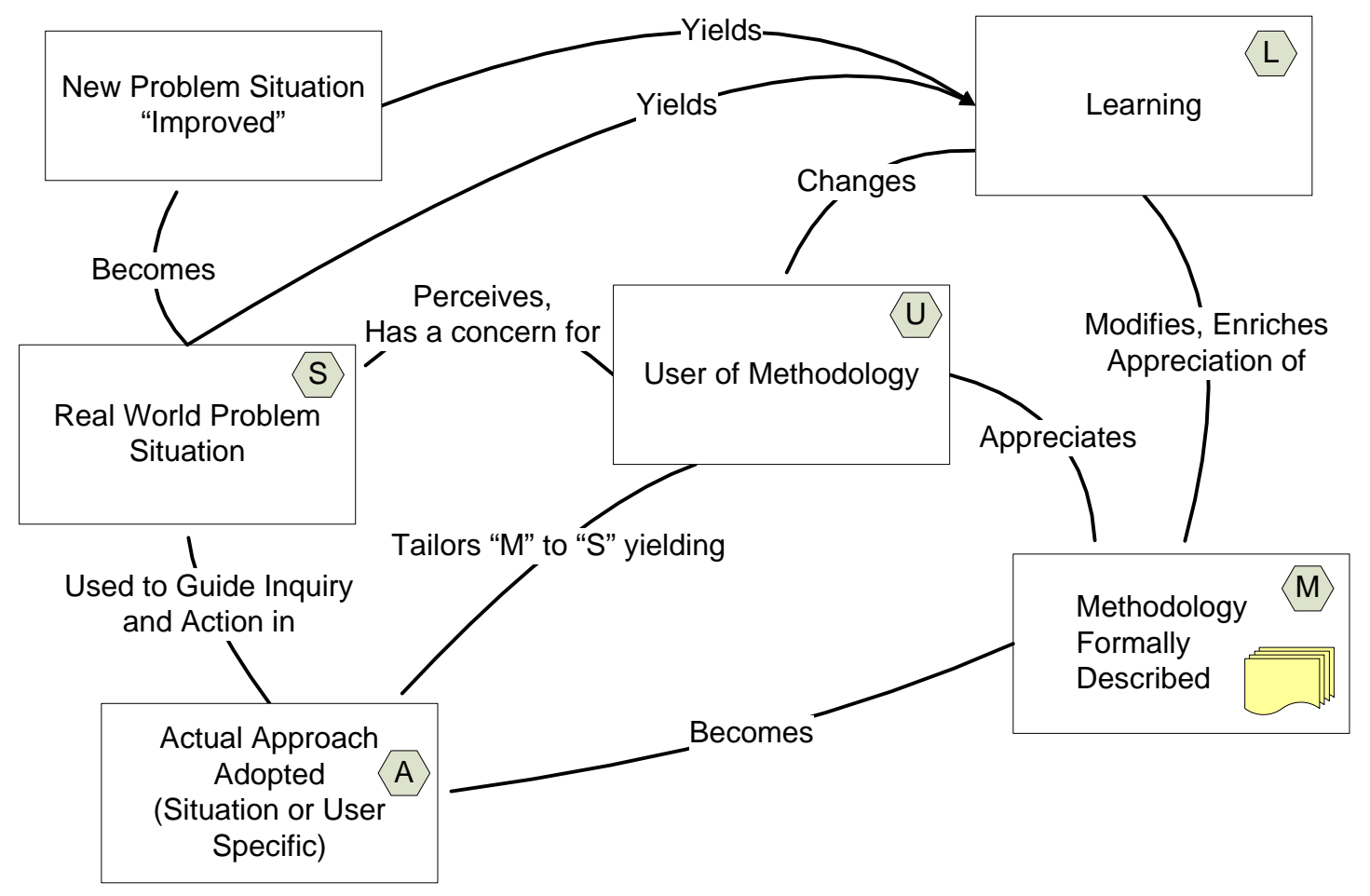

Figure 2: The LUMAS Model (from [Checkland 2000])

- A Tool (T) is an instrument that, when applied to a particular method, can enhance the efficiency of the task; provided it is applied properly and by somebody with proper skills and training. The purpose of a tool should be to facilitate the accomplishment of the "HOWs." In a broader sense, a tool enhances the "WHAT" and the "HOW." Most tools used to support systems engineering are computer-or software-based, and are also known as Computer Aided Engineering (CAE) tools.

Closely associated with methodology is an Environment (E) that consists of the surroundings, the external objects, conditions, or factors that influence the actions of an object, individual person or group [Martin 1996]. These conditions can be social, cultural, personal, physical, organizational, or functional. The purpose of a project environment should be to integrate and support the use of the tools and methods used on that project. An environment thus enables (or disables) the "WHAT" and the "HOW".'

The interrelationship of processes, methods, tools, and environments is graphically represented in Figure 3.

"Model” and "simulation" can be defined or classified in many ways. For example, the DHS Lexicon [DHS 2010] includes the following definitions:

- Model: approximation, representation, or idealization of selected aspects of the structure, behavior, operation, or other characteristics of a real-world process, concept, or system.

- Simulation: model that behaves or operates like a given process, concept, or system when provided a set of controlled inputs. 

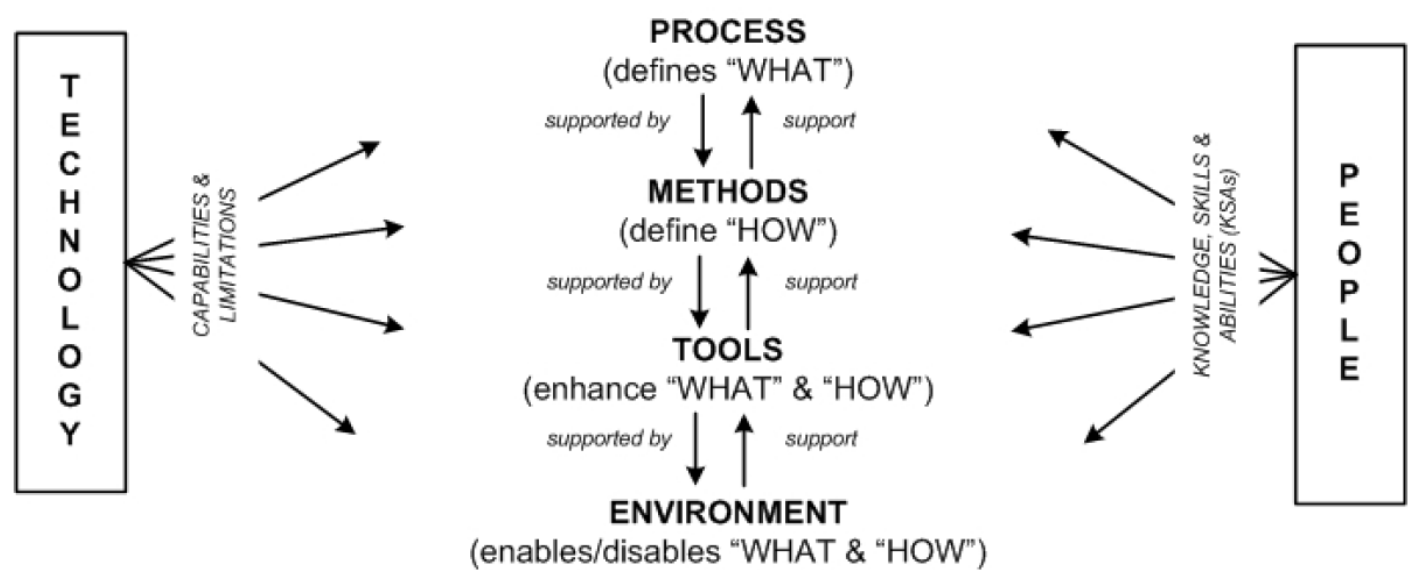

Figure 3: The Process, Methods, Tools, Environments Elements, and Effects of Technology and People (from [INCOSE 2008])

In addition, Department of Defense glossary [DoD 2010] provides the following definition.

- Modeling \& Simulation: Modeling and Simulation (M\&S): The discipline that comprises the development and/or use of models and simulations. M\&S is highly dependent upon Information Technology as defined in DoD Directive 4630.05, Interoperability and Supportability of Information Technology (IT) and National Security Systems (NSS), May 5, 2004.

a. The use of models, including emulators, prototypes, simulators, and stimulators, either statically or over time, to develop data as a basis for making managerial or technical decisions. The terms "modeling" and "simulation" are often used interchangeably, but simulations generally execute models over time, space, events, or other processes.

The focus of this document is on computer models and simulations - computer implemented physical, mathematical, process, phenomenological or other types of models. One perspective on the way in which computer models and simulations support methodology is modeled in Figure 4 (M in the LUMAS Model).

Models can broadly be divided into structural and behavior representations of systems, which could include mathematical or empirical modeling. Each of these types of models can be implemented using computer models for simulation and used to study questions of interest about a particular system. Various examples of model types are shown. This list of model types is not complete or exhaustive, but is meant to show typical applications of M\&S that support methodologies such as operations research, systems engineering, experimentation, or other types of analysis.

Although M\&S capabilities are tools in many different methodologies, M\&S using computers is itself a methodology with supporting processes, methods and tools. Figure 5 illustrates a simplified, generic process for development of computational M\&S capabilities to address a non-trivial engineering or scientific problem from the perspective of an M\&S developer. The process shown in Figure 5 also maps to the LUMAS model as shown in the figure. This process is also applicable to simpler problems where trivial steps may be combined. Also, the M\&S developer may be the problem solver and consumer of the $M \& S$ results such as an engineer addressing a systems design question or a program manager doing a 'what if' analysis to assess the risk to a program. 


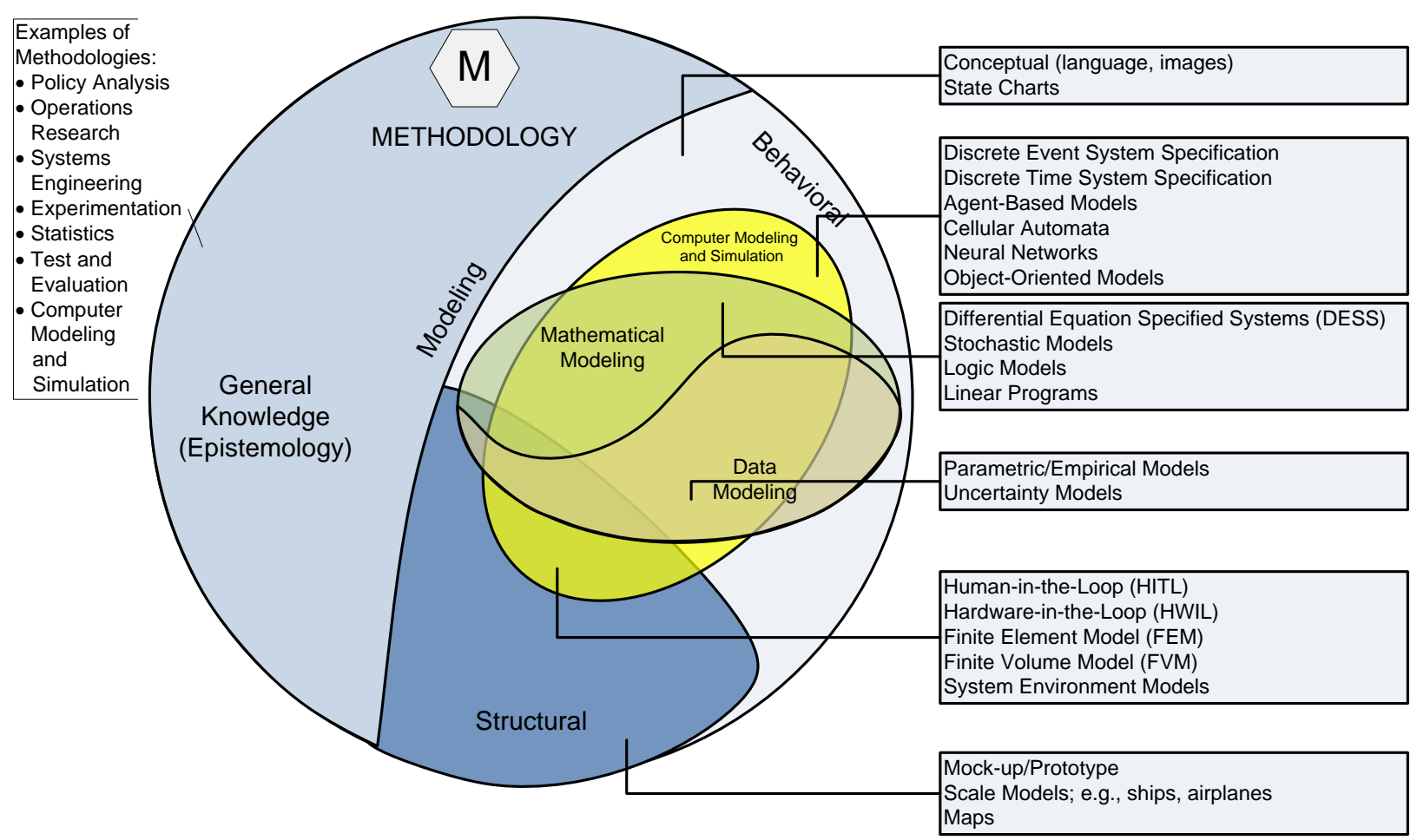

Figure 4: Modeling in methodology

The first step in the process includes the model or code developer (U) developing a clear understanding of what problem situation (S) the consumer of the M\&S results is trying to address. A conceptual model of the system or problem serves as a framework in developing and implementing the appropriate computer modeling capability (A) using the M\&S methodology (M) to address the question at hand. With a clear conceptual model in mind, developers have a number of choices to make in generating results:

- What data, knowledge, theories, or models are available or applicable to address the problem at hand?

- Is the data, knowledge, or understanding sufficient in both quality and quantity to address the problem at hand, or will additional data or observations be required to support development?

- What is the risk of using erroneous results, e.g., will these results be the only input to a decision, or will other sources of information be available to support decision making?

- How can the conceptual model be expressed mathematically or physically?

- What boundary and initial condition should be used?

- What modeling paradigm or approach would be most appropriate to implement the analysis?

- Given the developers' experience, what particular codes or capabilities would be most suitable for implementing the model, considering software, hardware, and other constraints and limitations?

- Given the code or computer capability has been developed, have any mistakes or errors been made in completing this or in entering the data?

- Given there are no mistakes or errors found in developing the capability or entering the data, are the results realistic, and do they make sense?

- What approach should be used to ensure that the results are correct?

- How do uncertainties and approximations affect the computational results?

- Given that everything else is correct, are the results suitable to address the problem at hand?

- How should the results and associated uncertainty be present for use in decision making? 


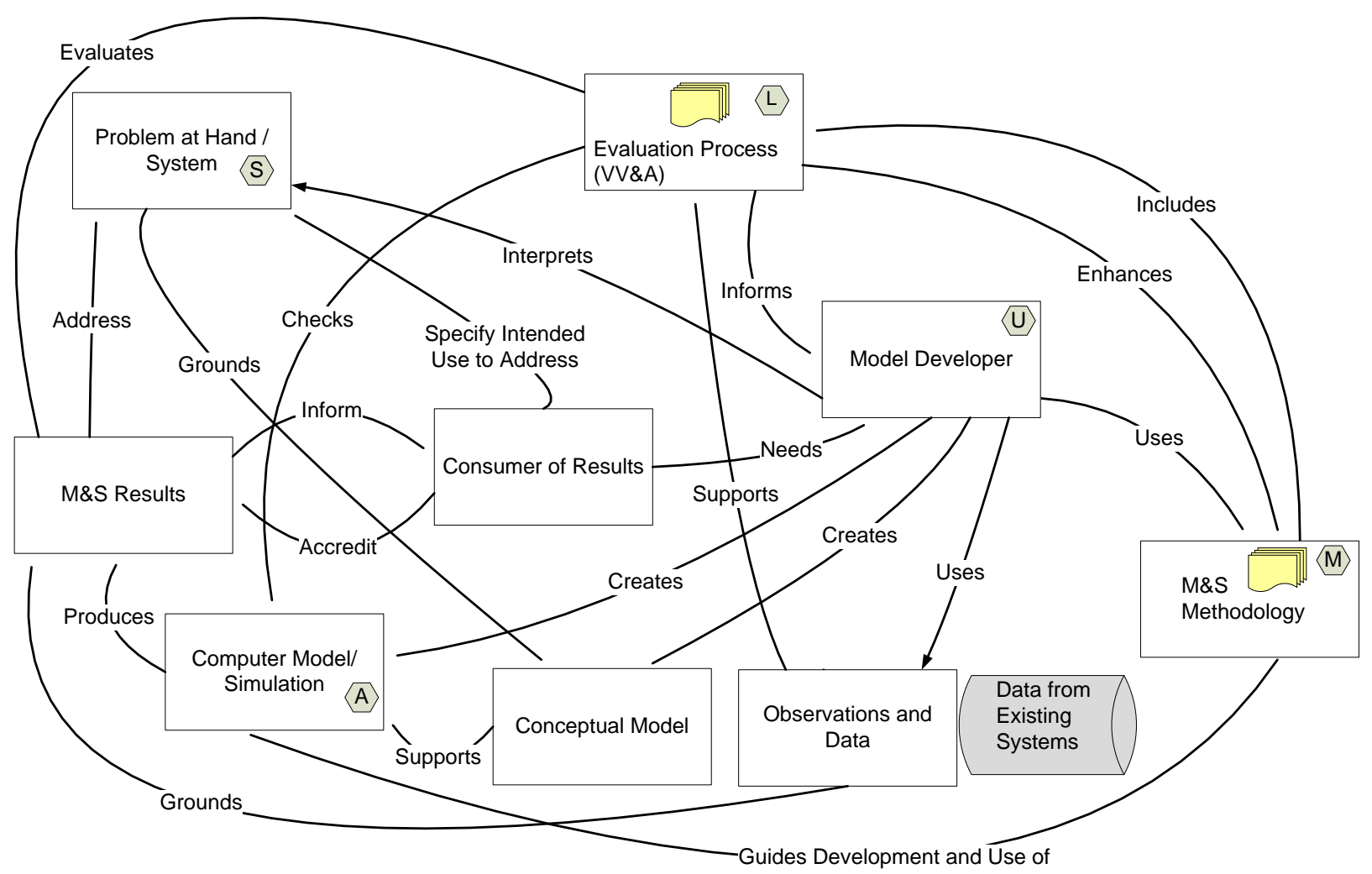

Figure 5: Computer Modeling and Simulation - Developer's Perspective

M\&S capabilities are used to model only selected aspects of a system and the models are implemented in a computing environment; therefore, the models need to be critically evaluated to ensure that the results are credible for their specific intended use, and this is typically done using an evaluation process (L) which is included in the M\&S methodology (M) and informs the model developer (U) of the quality of the $M \& S$ capability and results in addressing the problem at hand (S).

Evaluation of M\&S capabilities and results should take into account the many factors that affect the quality of the results including the level of understanding or knowledge of the issues being addressed and the experience level of model developers. Several organizations have developed processes and guidelines to address the credibility of M\&S capabilities. For example, DoD has a process for documentation, evaluation, and certification of M\&S results known as Verification, Validation and Accreditation (VV\&A) that is defined in a recommended practice guide [DoD 2006]. The DoD process is implemented in policy, which develops a common understanding of the major steps in the VV\&A process defined as below [DoD 2009]:

- Verification. The process of determining that a model implementation and its associated data accurately represents the developer's conceptual description and specifications.

- Validation. The process of determining the degree to which a model and its associated data are an accurate representation of the real world from the perspective of the intended uses of the model.

- Accreditation. The official certification that a model, simulation, or federation of models and simulations and its associated data are acceptable for use for a specific purpose. 
All M\&S capabilities should complete verification and validation (V\&V). M\&S capabilities used as the primary input to critical decision making, e.g., on cost, schedule, or performance of the system, should be formally accredited to certify that the results are credible for their intended use. Analysts and decisionmakers need to be aware of these sorts of issues when presented with computational modeling and simulation results.

[Balci 1998] developed a taxonomy and describes the use of different methods to evaluate M\&S capabilities and results based on software testing approaches. Figure 6 identifies these verification, validation, and testing methods or techniques which can be used to support an evaluation process such as VV\&A.

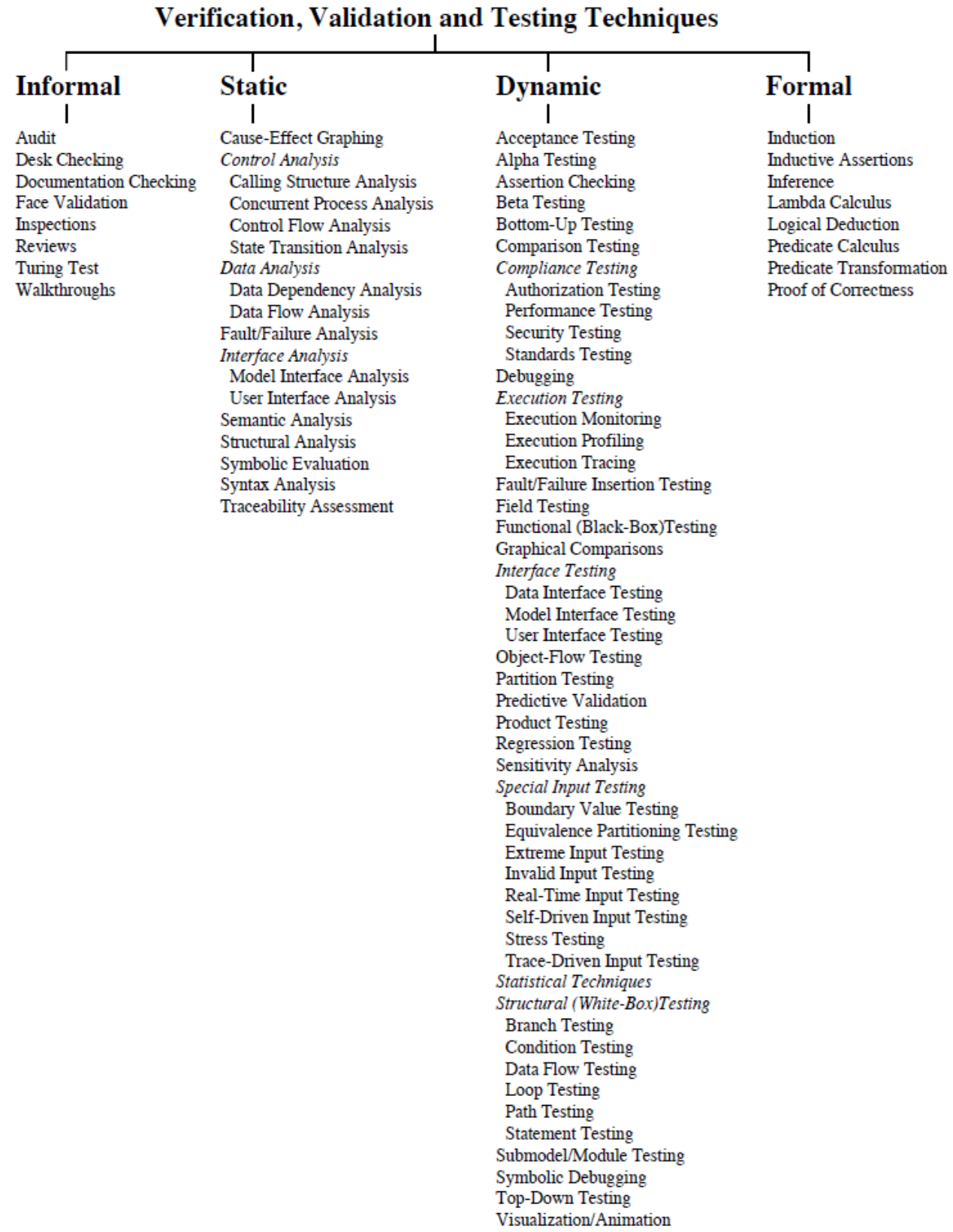

Figure 6: Taxonomy of Verification, Validation, and Testing Techniques (from [Balci 1998]) 
In addition to the use of recommended practices for conceptual modeling and ensuring model credibility, model developers should employ recommended practices for a number of other aspects. [Jain 2011] recommends best practices for modeling, simulation, and analysis for homeland security applications for the following aspects:

1. conceptual modeling

2. innovative approaches

3. software engineering

4. model confidence/ verification, validation and accreditation (VV\&A)

5. use of standards

6. interoperability

7. execution performance

8. user friendliness and accessibility

\section{Needs Analysis Overview}

Modeling and simulation should be used to support the needs of various managers, analysts, service providers, and first responders within the homeland security community. Most importantly, it must support the planning and response needs of the National Infrastructure Protection Plan (NIPP) partners including the Department of Homeland Security and other federal, state, local, tribal, territorial, and private sector organizations. The high level needs, identified below, have been derived from the NIPP, the National Infrastructure Simulation and Analysis Center (NISAC) mission statement [NISAC 2010], as well as a number of other DHS documents, and outside sources. A list of high level user/customer needs for incident management M\&S follows:

- Provide models of the normal operations of incident management systems, as well as the effects of epidemics, natural disasters, and terrorist attacks upon them to support analysis, planning, and response activities of homeland security incident management system partners.

- Establish incident management models, simulations, and data sets that support the national planning scenarios.

- Support planning for facility defense and security, selection and placement of incident management monitoring devices and system sensors to update status information, damage assessment, coordinated shutdown, and accelerated recovery of incident management systems.

- $\quad$ Provide M\&S capabilities to help establish priorities and potential mitigation strategies for protecting and/or isolating the impact of events on the population and incident management systems.

- Predict economic impacts of disasters and other relevant incident management events.

- Provide decision-makers the ability to assess policy, investment, and resource allocation options that address critical infrastructure needs - near and long term.

- Provide an integrating function that includes the identification and modeling of incident management system interdependencies. Supported interdependencies should include physical, geographic, cyber, and logical (see [Rinaldi 2004]); enable the integration of national, regional, local systems and data sources; bring together disparate users, information providers, and individual infrastructure sector leaders.

- Move towards predictive capabilities that use science-based tools to understand the behavior and expected performance of interrelated infrastructures (predictive capabilities should support various conditions, incident management systems, and event parameters such as time of day for events, level of demand for the incident management system, system weaknesses, capacity of facilities, mobilization resources, surge capacity, temporary support organizations, their systems, and functions). 
- Establish virtual capabilities that provide portals for nation-wide remote access and communications to incident management-related modeling, simulation, and analysis capabilities.

- Identify user data and interfaces needed for each incident management model and event type.

- Provide standard formats for the import and export of data between the portal and external data sources.

- Assist in planning for the backup and/or remote siting of critical data sources outside of regions affected by events, e.g., hurricane disaster areas.

- Provide simulation and analysis capabilities to a wide range of users that will enhance the understanding of vulnerabilities, risks, and event consequences to incident management systems.

- Provide education and training to public and private decision-makers on how to cope effectively with crisis events.

- Provide capabilities for coordinating incident management operations with other government agencies, and other organizations as well as conducting media interactions.

\section{Requirements Specifications}

This section provides a high level "shopping list" of requirements for incident management simulations and models. Requirement specifications are categorized into the following major areas:

- Intended Use (Section 5.1)

- Functional requirements (Section 5.2)

- Data requirements (Section 5.3)

- User interface requirements (Section 5.4)

- Performance requirements (Section 5.5)

- Credibility and Evaluation Requirements (Section 5.6)

A specific system implementation may contain only a subset of these requirements as determined by program management and/or the customer/user.

\subsection{Intended Use}

Incident management models and simulations will be used by incident managers, emergency planners, first responders, and training personnel to:

a) Analyze the resource requirements, behavior, and performance of incident management systems.

b) Conduct training exercises, drills, emergencies, tests, alerts, real world incidents, and planning for national security events.

c) Determine the readiness of incident management systems to respond to various types of emergencies.

d) Model past incidents for education, training, and analysis purposes.

\subsection{Functional Requirements}

This section identifies possible functions that may be included in incident management models and simulations.

a) Provide functions to create high level models of responder evolutions over time to support system performance and resource analysis.

b) Provide training and exercise simulations for incident management that provide functionality for various incident and exercise parameters, exercise control, and after action reviews. 
c) Provide various types of training implementations including table top exercises, 2D and 3D computer gaming, and immersive virtual reality environments.

d) Provide capabilities to refine simulations based on actual incident data, field measurements, and sensor data.

e) Support vector and raster representations of geography, buildings, and other structures.

f) Support a range of different grid resolutions on incident management models, maps and displays, e.g., 30 meter, 100 meter, 1 kilometer, 10 kilometer.

g) Support the integration and/or distributed execution of interrelated models including hazardous material release exposure and hazard effects, critical infrastructure systems, healthcare systems, weather, and watershed flows.

h) Identify regions where the exposed population will experience life threatening, serious long-lasting or notable effects from incidents.

\subsection{Data Requirements}

This section identifies input and output data types that may be supported for incident management models and simulations.

a) Structure of responder organizations and inventory of responder resources

b) Standard incident management processes and procedures

c) Message logs and incident time lines

d) Specification of the incident area including event types and parameters, timing of events, schedule of responder activities, terrain and buildings in affected areas

e) Demographics data: population location, density, and attributes by time of day

f) Meteorological data: observed and forecast weather conditions that may affect an incident including wind speed, direction, and precipitation

g) Plume data hazardous material releases and explosions

h) Support of appropriate data standards in model implementations, training and exercise simulations, e.g., SCORM - Shareable Content Object Reference Model [ADL 2011]

\subsection{User Interface Requirements}

This section identifies user interface capabilities that may be supported for incident management models and simulations.

a) Provide capabilities to configure simulation runs with specific incident types and associated parameters, affected populations, responder resources, weather conditions, and geographic regions.

b) Generate graphical views of incident and responder activities over a 2D or 3D representation of area of interest at different levels of resolution.

c) Provide user control mechanisms that affect rapid execution/playback of simulation runs to move forward and back to desired points in time.

d) Use various DHS standard symbology, maps, and representation schemes to display incident parameters, resource locations, and timelines.

e) Provide virtual reality interfaces to support 3d gaming for incident management exercises.

f) Provide exercise controller interfaces to effect the initiation, execution, as well as playback of exercise simulations for after action reviews and hot washes.

g) Provide interfaces to generate still image and video files that can be used to transfer results for viewing or playback using other software tools. 


\subsection{Performance Requirements}

This section identifies possible performance considerations for incident management models and simulations.

a) Support time scaling of models and simulations and abilities to move forward rapidly in time to focus on events of interest (real-time and faster than real-time to support analysis during actual incidents).

b) Provide for updates from real time meteorological databases and observations.

c) Share model predictions with other software applications.

d) Provide capabilities for interoperable networked implementations at different sites by different organizations.

\subsection{Credibility and Evaluation Requirements}

This section identifies approaches that may be used to evaluate and determine the credibility of incident management models and simulations.

a) Conduct walkthroughs of simulation models of incident management simulations and models with experienced incident managers and first responders.

b) Compare results and predictions of incident management models against past events using historical data.

c) Conduct side by side training exercises using conventional techniques (e.g., tabletop exercises) and computer-based simulations to compare effectiveness in achieving intended goals such as training objectives, realism, and exercise resource requirements.

\section{Identification of $M \& S$ Resources}

This section identifies existing M\&S resources that support incident management and are possibly relevant to meeting some of the needs and requirements presented in sections 4 and 5 . Resources that primarily support other $M \& S$ areas or domains, e.g., critical infrastructure, are not included. Topics addressed include:

- $\quad$ Projects, facilities and capabilities (Section 6.1)

- Simulation models and tools (Section 6.2)

- Relevant standards and Guidelines (Section 6.3)

- Data sources (Section 6.4)

\subsection{Projects, Facilities, and Capabilities}

A number of projects have been initiated to address incident management $M \& S$ issues, although some have been sponsored by DHS, there have been others conducted by outside organizations both within and outside of the U.S. A preliminary list of projects follows:

Complex Event Modeling, Simulation, and Analysis Project: This project focuses on interdependencies, cascading effects, and the dynamics of multi-event and multi-vector attacks. This effort will provide significant improvements in timelines, quality and usability of information to provide decision makers upto-date information to make informed decisions during an event. The program will leverage the capabilities developed for the Critical Infrastructure Protection Decision Support System (CIPDSS) and sector-specific modeling, simulation and analysis (MSA). The project is within the Infrastructure 
Protection Thrust Area and the Modeling, Simulation and Analysis Program of the Infrastructure and Geophysical Division [DHS 2009b].

Emergency Operations Training Center (EOTC), Texas Engineering Extension Service: Located in College Station, Texas, the center is a state-of-the-art emergency management and incident command training facility operated by the National Emergency Response and Rescue Training Center, a division of the Texas Engineering Extension Service. The EOTC's goal is to provide participants (including government agencies, corporate industrial teams, and jurisdictions from across the nation) the skills they need to respond to, manage, and recover from large-scale incidents. The EOTC provides a wide spectrum of possible operations, ranging from the incident command post perspective to the emergency operations center and multi-agency coordination viewpoint at the local, regional or state levels. The overall incident management structure used in the EOTC replicates the Incident Command System and follows the National Incident Management System (NIMS) as required in the National Response Framework (NRF). The 32,000-square-foot EOTC uses state-of-the-art simulation and computer-based technologies to train incident managers, supervisors, and jurisdiction officials in the management of a large-scale crisis using a unified command approach, which can be tailored to any group [TEEX 2010].

Incident Management Simulation Laboratory (Simlab), U.S. Fire Administration, Emmitsburg, MD: The laboratory is configured to afford candidates "real-world" training in a variety of emergency situations encompassing incidents such as dwelling fires, commercial and large structure fires, catastrophic disasters and major emergency events, such as hazardous materials releases and mass casualty incidents. 3D computer models are used to provide visual clues, which are generated through the use of commercial offthe-shelf special effects, graphics, and animation software, and controlled through a standard personal computer by menu driven software. The goal of the simulation training is to provide the student with a variety of visual and auditory cues that will enhance the decision-making process in practical situations. This training provides realistic experience in the application of the principles of the National Incident Management System (NIMS) and conversancy with the recognition primed decision-making model of higher order cue-based decision-making [USFA 2010c].

Integrated Modeling, Mapping, and Simulation (IMMS) program and Standard Unified Modeling and Mapping Integration Toolkit (SUMMIT): The IMMS program is designing and prototyping a simulation and collaboration environment for linking together existing and future modeling and simulation tools to enable analysts, emergency planners, and incident managers to more effectively, economically, and rapidly prepare, analyze, train, and respond to real or potential incidents. When complete, the IMMS program will demonstrate an integrated modeling and simulation capability that supports emergency managers and responders with 1) conducting "what-if” analyses and exercises to address preparedness, analysis, training, operations, and lessons learned, and 2) effectively, economically, and rapidly verifying response tactics, plans and procedures. IMMS program is developing the Standard Unified Modeling and Mapping Integration Toolkit (SUMMIT), a software framework for rapidly linking together these resources, and supporting collaboration across user communities. SUMMIT will enable discovery and exploitation of models, simulations, data, and archived analyses that are relevant to a specific scenario or event of interest and bringing together users and modeling resources from many locations while ensuring that access to existing data and models is controlled by the resource owners [DHS 2010d].

National Exercise Simulation Center, Federal Emergency Management Agency (FEMA): The National Exercise Simulation Center (NESC) is a Congressionally-mandated state-of-the-art training and exercise facility within FEMA Headquarters, and serves as a key element within the Federal Coordination Center (FCC). The FCC draws on the specialized capabilities of its FEMA elements, including the Disaster Operations Directorate, the National Preparedness Directorate, the Office of National Capital Region Coordination, and others as needed, to collaborate with and support deliberate planning, training, exercises and response operations coordination [FEMA 2010h]. The NESC is focused on utilizing 
decision support simulation to increase exercise realism and immersion in lifelike scenarios. It integrates Human Based Simulations (actors) and Computer Based Simulations for the purpose [Holtermann 2010].

Simulation Based Incident Planning and Response project: This project provides FEMA analysts, decision makers, policy makers as well as emergency managers, and operators an integrated modeling and simulation capability to effectively, economically, and rapidly verify and validate response tactics, plans and procedures and to conduct "what-if" type analyses prior to an incident (preparedness, analysis, training) and during/after an incident (operational, lessons learned) [DHS 2009b].

Security and Incident Modeling Lab (SIMLAB), U.S. Secret Service: SIMLAB uses MS\&A assets and technologies to develop simulated training exercises for the Service's protective detail teams, tactical response units and counter-surveillance units. SIMLAB also employs modeling and simulation for planning and analysis. These projects are typically for prototyping emergency preparedness strategies, defensive and counter-measure analyses, vulnerability and risk assessments, resource threshold studies and many other contingency examinations [U.S. Army 2007].

Training, Exercise \& Lessons Learned (TELL) project: The TELL project is developing a federated simulation-based training and exercise capability that uses advanced computer models and will allow responders at all levels to affordably train and exercise for large and complex events in a virtual/constructive/live environment. TELL will link multiple agencies, functions, and jurisdictions to improve preparedness and decision-making for emergency responders and managers. TELL incorporates training objectives, scenarios, and metrics defined by other programs, and the capability to capture lessons learned to improve future emergency response capabilities [DHS 2009b].

\subsection{Simulations, Models and Tools}

A number of incident management modeling and training tools have been developed through the efforts of federal agencies, universities, research organizations and commercial companies. This section lists existing tools that have been identified through Internet searches and site visits to known organizations involved in M\&S of incident management systems. The tools are arranged alphabetically based on their developer's acronyms, or in some cases, abbreviations assigned by the authors for purposes of the readability of this document.

\begin{tabular}{|l|l|}
\hline Tool Acronym & \multicolumn{1}{c|}{ Brief Description } \\
\hline ACATS & $\begin{array}{l}\text { Advanced Conflict and Tactical Simulation (ACATS) software is for training first } \\
\text { responders in the event of a chemical, biological, radiological (CBR), or nuclear } \\
\text { terrorist attack in an urban scenario. ACATS provides the ability to model } \\
\text { contaminant flows throughout urban environments and into buildings through their } \\
\text { HVAC systems. ACATS is able to look at conceptual operations through additional } \\
\text { modeling capabilities that include human injuries and fatalities, portable CBR sensors, } \\
\text { building evacuation, crowd behavior, and responder tactics [LLNL 2010]. }\end{array}$ \\
\hline ADMS & $\begin{array}{l}\text { Advanced Disaster Management Simulator (ADMS) is available in two versions. } \\
\text { ADMS-COMMAND is an on-scene incident command training simulator for first } \\
\text { responders and on-scene commanders in mono and multi-agency operations, from } \\
\text { basic incidents to complex disasters. It bridges the gap between tabletop exercises and } \\
\text { real world experience. Common learning objectives are Command, Control, } \\
\text { Coordination and Communication [ETC 2010a]. }\end{array}$ \\
\hline
\end{tabular}




\begin{tabular}{|c|c|}
\hline$A D M S-E O C$ & $\begin{array}{l}\text { ADMS-EOC is for training strategic level incident management teams, and } \\
\text { Emergency Operations Center personnel. ADMS-EOC includes additional learning } \\
\text { objectives such as Planning, Mapping, Logistics and Information Management. } \\
\text { ADMS-EOC can be combined with ADMS-COMMAND to train on-scene and } \\
\text { strategic command at the same time [ETC 2010b]. }\end{array}$ \\
\hline ASOCC & $\begin{array}{l}\text { Area Security Operations Command and Control (ASOCC) is an interactive } \\
\text { computer-based system designed to provide real-time situational awareness } \\
\text { capabilities. It can provide graphic and imagery-based photographs and maps with } \\
\text { supporting data, collaboration capabilities, a log and alert function, and a means to } \\
\text { access and display updated information from web-based status board and databases. It } \\
\text { was originally developed by the Defense Information Systems Agency (DISA) for } \\
\text { U.S. military use. ASSOC may provide access to data on current situation needed for } \\
\text { simulation of response options [CWID 2004]. }\end{array}$ \\
\hline BioDAC & $\begin{array}{l}\text { Biological Weapons of Mass Destruction Decision Analysis Center has been } \\
\text { developed at Sandia. It combines multiple simulations for analysis of decisions } \\
\text { related to a biological agent release. The simulation includes: threat, population, } \\
\text { health monitoring, environmental monitoring, and incident management roles of } \\
\text { multiple involved groups. It was used to support an exercise in San Diego. Insights } \\
\text { gained from the exercise and analyses have been incorporated in to the development } \\
\text { of National Bio-Monitoring Architecture [Linebarger 2007]. }\end{array}$ \\
\hline CEMPlanner & $\begin{array}{l}\text { Comprehensive Emergency Management Planner (CEMPlanner) is a web-based } \\
\text { planning system that creates industry compliant plans. It provides customizable } \\
\text { templates that collect the information and generates emergency operation plans } \\
\text { (EOP), site plans and all of their components. The software is included in this list } \\
\text { since it may be possible to input the generated plans in to simulation models for } \\
\text { evaluation [Previstar 2008]. }\end{array}$ \\
\hline Commander & $\begin{array}{l}\text { Commander is a situational awareness tool built on the Geospatial Information } \\
\text { System (GIS) application developed by Intergraph known as GeoMedia. It includes } \\
\text { other critical information such as vehicle tracking, plume cloud distribution, dynamic } \\
\text { building and vehicle gate status. It also allows resource tracking, interfacing with the } \\
\text { Warfighter Protection Lab (WPL) simulation suite, and as a front end driver for the } \\
\text { Center for Domestic Preparedness Incident Command Course tool [Belk 2006]. }\end{array}$ \\
\hline CPS & $\begin{array}{l}\text { The Continual Preparedness System (CPS) is primarily a crisis information } \\
\text { management software (CIMS) from Previstar, but it includes predictive modeling } \\
\text { capabilities including a bio-agents model set for infectious and non-infectious } \\
\text { diseases and hurricane debris model. A model builder is available for users to build } \\
\text { their own models [Previstar 2008]. }\end{array}$ \\
\hline CrowdSim & $\begin{array}{l}\text { Developed at LANL, CrowdSim is an agent-based framework for simulating large } \\
\text { crowd dynamics. It simulates behavior of pedestrians in a crowd. It has been used to } \\
\text { model the national mall. It was originally built on Repast and includes event handler } \\
\text { and visualization. It is now being enhanced using particle and cell modeling } \\
\text { computational techniques [Saeger 2007]. }\end{array}$ \\
\hline
\end{tabular}




\begin{tabular}{|c|c|}
\hline DI-Guy & $\begin{array}{l}\text { Dismounted Infantry Guy (DI-Guy) Scenario was developed by Boston Dynamics as } \\
\text { an interactive, three-dimensional simulation depicting individuals and their behaviors. } \\
\text { The Warfighter Protection Lab employs DI-Guy to create scenarios and control the } \\
\text { placement and behavior of characters in detailed urban environments, allowing } \\
\text { emergency responders to train for situational scenarios outside of actual emergency } \\
\text { events [BostonDyn 2007]. }\end{array}$ \\
\hline DrillSim & $\begin{array}{l}\text { The DrillSim simulator is a multi-agent crisis simulator that can play out the activities } \\
\text { of the response (e.g., evacuation) during a crisis from the perspective of IT solution } \\
\text { integration. The simulator can model different response activities at both the macro } \\
\text { and micro level, and model the information flow between different entities. IT } \\
\text { solutions, models, etc. can be plugged in at different interfaces between these } \\
\text { activities to study the effectiveness of research solutions in disaster management and } \\
\text { tested for utility in disaster response. DrillSim is being developed at the University of } \\
\text { California at Irvine [Massaguer 2006]. }\end{array}$ \\
\hline$E M^{*} E S$ & $\begin{array}{l}\text { Emergency Management Exercise System (EM*ES) is a scenario-driven simulation- } \\
\text { supported exercise environment that offers great flexibility with respect to the } \\
\text { targeted training audience and types of incidents introduced in the scenario. It is } \\
\text { available in both web-based and distributed application variants. It can be used } \\
\text { operationally as a command and control system and blurs the line between training } \\
\text { and operations. It provides a common operational picture for emergency management } \\
\text { personnel thereby facilitating a higher state of situational awareness for all } \\
\text { participants. It is fully compliant with the National Incident Management System } \\
\text { (NIMS) [Wall 2009]. }\end{array}$ \\
\hline EMST & $\begin{array}{l}\text { Emergency Management Staff Trainer (EMST) is a multi-player simulation-based } \\
\text { exercise system geared toward emergency response professionals. EMST provides } \\
\text { scenarios, exercises, and other capabilities that support the structure of the National } \\
\text { Incident Management System (NIMS), including both individual and team training } \\
\text { for the fifteen FEMA Emergency Support Functions (ESFs). EMST is an all-hazards } \\
\text { trainer, with a range of scenarios including natural disasters, terrorist attacks, } \\
\text { pandemic, and civil unrest. Each EMST exercise scenario presents an unfolding } \\
\text { situation through email, news videos, website articles, simulated phone calls, } \\
\text { meetings, maps, images, and other injects, and requires the participant to take action } \\
\text { to respond to or mitigate the situation [ECS 2010]. }\end{array}$ \\
\hline Ground T & $\begin{array}{l}\text { Ground Truth is designed for high-level incident commanders who need to understand } \\
\text { how to best allocate their resources. The game also educates users on the dangers } \\
\text { faced by on-scene emergency responders. The serious game has been developed at } \\
\text { Sandia National Laboratory at Livermore with support from University of Southern } \\
\text { California's GamePipe Laboratory [Janes 2007]. }\end{array}$ \\
\hline Hydra & $\begin{array}{l}\text { Hydra is a training simulator designed to provide incident command officers and } \\
\text { senior-investigating officers with training that is as close to the real thing as possible. } \\
\text { The Hydra system provides students with a chance to experience the management of } \\
\text { large-scale criminal investigations and major critical incident command. It includes } \\
\text { support for fast-time and slow-time decision making, tactical and strategic levels of } \\
\text { command, complex information and action flow, simulated resource management, } \\
\text { and decision tracking and audit [Hydra 2010]. Developed in the United Kingdom, the }\end{array}$ \\
\hline
\end{tabular}




\begin{tabular}{|c|c|}
\hline & simulation system is in use at the Los Angeles Police Department [Pittman 2010]. \\
\hline IC2020 & $\begin{array}{l}\text { Incident Command } 2020 \text { (IC2020) is being developed at Dartmouth College as a } \\
\text { prototype of a next-generation incident command software architecture that combines } \\
\text { situational awareness, embedded simulation, and planning functions. It is designed to } \\
\text { be a realization of the NIMS incident command system and common operational } \\
\text { picture, and to be a research and demonstration platform for simulation, sensor } \\
\text { integration, and human factors studies. The simulation that supports IC2020 manages } \\
\text { the state of simulated objects (vehicles, personnel, equipment) and generates event } \\
\text { notifications [McGrath 2006]. }\end{array}$ \\
\hline ICATS & $\begin{array}{l}\text { Incident Command Analytic Training System (ICATS) is being developed at LLNL } \\
\text { with ACATS at its core (see earlier entry for ACATS). ICATS is a collection of } \\
\text { simulations and technologies that provides a solution for the training of our federal, } \\
\text { state, and local emergency incident managers. ICATS is being used to evaluate and } \\
\text { train incident command staff making critical decisions in a stressful virtual- } \\
\text { catastrophe environment. It links them simultaneously from distributed locations and } \\
\text { jurisdictions and enables them, individually and collectively, to experience the } \\
\text { immediate consequences of their decisions and determine the best course of response } \\
\text { [LLNL 2010]. }\end{array}$ \\
\hline ICWM & $\begin{array}{l}\text { Incident Command Workflow Modeling has been developed at Monmouth } \\
\text { University. It provides on the fly modification and validation of workflow for ICS. It } \\
\text { has been designed with volunteers in mind who may need intuitive features for the } \\
\text { description and modification of the workflow [Wang 2008]. }\end{array}$ \\
\hline $\begin{array}{l}\text { Incident } \\
\text { Commander }\end{array}$ & $\begin{array}{l}\text { Incident Commander is a PC-based simulation developed for the U.S. Department of } \\
\text { Justice by BreakAway to train first responders, emergency personnel and multi- } \\
\text { agency personnel to plan, and prepare for emergency and crisis situations. Incident } \\
\text { Commander can train up to } 16 \text { players simultaneously, with users assuming roles as } \\
\text { either the commander or members of the operations team. The game simulates various } \\
\text { crisis scenarios, including a natural disaster, a school hostage situation, and a } \\
\text { terrorism incident in a hypothetical any town, USA setting [Breakaway 2010]. }\end{array}$ \\
\hline JNEM & $\begin{array}{l}\text { Joint Non-kinetic Effects Model (JNEM) developed at the Jet Propulsion Lab is a tool } \\
\text { developed for DoD requirements to model non-kinetic effects such as the reaction of } \\
\text { crowd and civilians in areas surrounding a force action. The tool models a number of } \\
\text { situations such as power outages, water shortages, and sewage spill, and their impact } \\
\text { on civilian mood. Civilian concerns and mood are in turn modeled based on } \\
\text { perceived autonomy, safety, culture and quality of life. The tool is also applicable to } \\
\text { homeland security scenarios and has been used to support Ardent Sentry - Northern } \\
\text { Edge } 07 \text { exercise conducted jointly by DoD and DHS [Chamberlain 2006]. }\end{array}$ \\
\hline LMIS & $\begin{array}{l}\text { LMIS is a simulation-based exercise and training capability whose focus is on disaster } \\
\text { response and recovery. LMIS is derived from DoD simulations including the Joint } \\
\text { Semi Automated Forces (JSAF) code base, which is a highly scalable civilian model } \\
\text { utilizing entity-level modeling with aggregate-level network data and behavior } \\
\text { models; the Warfighters Simulation (WARSIM), an aggregate-level command and } \\
\text { staff training simulation with in-depth logistics models and interfaces to operational } \\
\text { command \& control (C2) and situational awareness systems; and a variety of }\end{array}$ \\
\hline
\end{tabular}




\begin{tabular}{|c|c|}
\hline & $\begin{array}{l}\text { additional models and capabilities specific to the domain of disaster response [Beck } \\
\text { 2009]. }\end{array}$ \\
\hline LPAT & $\begin{array}{l}\text { Logistics Process Analysis Tool (LPAT) has been developed at ANL. The LPAT } \\
\text { model helps the planners quantitatively evaluate the transportation and logistics } \\
\text { aspects of their emergency plans through a "from warehouse to citizen" simulation. } \\
\text { Planners are able to use LPAT's macro-level logistics and transportation component } \\
\text { independently or together with its micro-level process simulation component to test, } \\
\text { analyze and understand the interactive elements of the supply chain, the impact of } \\
\text { conflicting priorities, and the consequences of logistics decisions before } \\
\text { implementation of the plan. By using LPAT, planners can define the range and scope } \\
\text { of a logistical operation and predict the type and quantity of assets required for a } \\
\text { particular response or recovery effort [ANL 2010a]. }\end{array}$ \\
\hline OREMS & $\begin{array}{l}\text { Oak Ridge Evacuation Modeling System (OREMS) can be used to estimate } \\
\text { evacuation time and to develop evacuation plans for different events or scenarios } \\
\text { (e.g., good vs. bad weather conditions, day vs. nighttime evacuations) for user-defined } \\
\text { spatial boundaries. The system permits experimentation with alternate routes, } \\
\text { destinations, traffic control management strategies, and evacuee response rates. For } \\
\text { every scenario it is possible to identify evacuation or clearance times, traffic } \\
\text { operational characteristics (e.g., average evacuation speed), bottlenecks, and other } \\
\text { information necessary to develop effective evacuation plans and to conduct } \\
\text { transportation infrastructure vulnerability studies [ORNL 2010a]. }\end{array}$ \\
\hline PLAN C & $\begin{array}{l}\text { Planning with Large Agent-Networks against Catastrophes (PLAN C) is an agent- } \\
\text { based simulation tool for emergency managers, urban planners and public health } \\
\text { officials to prepare and evaluate Pareto-optimal plans to respond to urban catastrophic } \\
\text { situations. PLAN C uses a large-scale computational multi-agent based disaster } \\
\text { simulation framework involving thousands of agents. It has been able to simulate the } \\
\text { complex dynamics of emergency responses in different urban catastrophic scenarios } \\
\text { (e.g., chemical agent, bomb explosion, food poisoning, small pox). It can devise plans } \\
\text { that optimize multiple objective functions (e.g., number of casualties, economic } \\
\text { impact, time to recovery) in terms of their Pareto frontier in a high-dimensional space; } \\
\text { for this purpose, it uses an evolutionary genetic search algorithm. It is designed to be } \\
\text { used and parameterized by relatively unsophisticated users. The technology can be } \\
\text { transferred to any urban setting, to multiple computer platforms, and to different } \\
\text { modes (offline or online) of planning [NYU 2009]. }\end{array}$ \\
\hline Play2Train & $\begin{array}{l}\text { Play2Train is a virtual training space in SecondLife designed to support Strategic } \\
\text { National Stockpile (SNS), Simple Triage Rapid Transportation (START), Risk } \\
\text { Communication and Incident Command System (ICS) training. This virtual } \\
\text { environment, which currently comprises a town and two hospitals, spreads over three } \\
\text { islands Asterix, Obelix and Getafix (65536 x } 3 \text { sq. meters). Play2Train provides } \\
\text { opportunities for training through interactive role playing. This project implements } \\
\text { one of the distance learning methodologies proposed by the Idaho Bioterrorism } \\
\text { Awareness and Preparedness program (IBAPP) project [ISU 2010]. }\end{array}$ \\
\hline Restore & $\begin{array}{l}\text { Developed at ANL, Restore models complex sets of steps required to accomplish a } \\
\text { goal, such as repairing a ruptured natural gas pipeline, when the time required to } \\
\text { complete a step may be uncertain due to such factors as the time of day, weather, and }\end{array}$ \\
\hline
\end{tabular}




\begin{tabular}{|l|l|}
\hline & $\begin{array}{l}\text { availability of crew. Restore allows a user to estimate the time and cost (which may } \\
\text { also be uncertain) needed to achieve an intermediate stage of completion, as well as } \\
\text { overall completion. It can also model workarounds and a simultaneous complete } \\
\text { repair to obtain a distribution for the earliest time until service (either temporary via } \\
\text { the workaround or normal via complete repair, whichever comes first) can be } \\
\text { restored. The tool also identifies the "most active path" through the network of tasks. } \\
\text { It generates output graphs of probability distributions for overall and intermediate } \\
\text { completion times [ANL 2010b]. }\end{array}$ \\
\hline VISAC & $\begin{array}{l}\text { Visual Interactive Site Analysis Code (VISAC), developed at ORNL, is a Java-based } \\
\text { expert system that provides mission planners with a coordinated capability to predict } \\
\text { and analyze the outcomes of different accidents/incidents at various nuclear and } \\
\text { industrial facilities. The incidents can range from simple individual equipment } \\
\text { sabotage to complex sorties that utilize a range of military weapons, simulated truck } \\
\text { or car bombs, or satchel charges. The target facility is generated by either customizing } \\
\text { existing 3-D CAD models for near real-time analysis or creating a new model from } \\
\text { scratch. Using event/fault tree methodology, VISAC provides the probability of } \\
\text { facility kill, the probability of undesirable collateral effects (chemical or radiological } \\
\text { releases), and an estimate of facility down time [ORNL 2010b]. }\end{array}$ \\
\hline
\end{tabular}

\subsection{Relevant Standards and Guidelines}

This section identifies standards and guidelines that are potentially relevant to the development of M\&S applications for incident management systems. The standards and guidelines may include mechanisms and formats for the interchange of data, data storage, generation of information displays, integration of systems, and/or conceptualization and design of incident management M\&S applications. Subsection 1 includes the standards that are specific to incident management domain. The following subsections list standards that are common across the homeland security applications of M\&S and focus on conceptual modeling, distributed simulation, geographical information system (GIS), communications, and training respectively.

\subsubsection{Domain Specific Standards}

\begin{tabular}{|l|l|}
\hline \multicolumn{1}{|c|}{ Standard Title } & \multicolumn{1}{c|}{ Overview } \\
\hline $\begin{array}{l}\text { Advisory and Notification Markup } \\
\text { Language (ANML) }\end{array}$ & $\begin{array}{l}\text { Description: The Open Security Organization is developing an } \\
\text { Advisory and Notification Markup Language (ANML). ANML } \\
\text { is an XML-based specification for describing advisories and } \\
\text { other types of notifications. ANML intends to solve the } \\
\text { inconsistent use of terminology by software vendors in their } \\
\text { advisories and make it easy for applications to read these } \\
\text { advisories. Although ANML will have its biggest impact for } \\
\text { security advisories, it can be used for any type of notification } \\
\text { [OASIS 2010a]. } \\
\text { Standard Type: Industry specification } \\
\text { Organization: Open Security Organization } \\
\text { Classification: Domain-specific Integration Interface }\end{array}$ \\
& \\
\hline
\end{tabular}




\begin{tabular}{|c|c|}
\hline $\begin{array}{l}\text { Caltech-USGS Broadcast of } \\
\text { Earthquakes (CUBE) Message } \\
\text { Format }\end{array}$ & $\begin{array}{l}\text { Description: A message format used to report earthquake } \\
\text { broadcast messages from the Caltech-USGS Broadcast of } \\
\text { Earthquakes (CUBE) system, a real-time notification system for } \\
\text { earthquake information. A CUBE message consists of an } \\
\text { identification segment, earthquake's time, location, magnitude, } \\
\text { and depth. CUBE format is a fixed-format, card-like version of } \\
\text { the information in the merged catalog. It contains the same } \\
\text { information provided in the XML format, except that there is no } \\
\text { information on 'duplicate' event ids, which occur when networks } \\
\text { other than the authoritative network submits information on the } \\
\text { same event. The minimum magnitude of events included in the } \\
\text { CUBE catalog varies from region to region depending upon the } \\
\text { density of the reporting networks [USGS 2010]. } \\
\text { Standard Type: CUBE } \\
\text { Organization: California Institute of Technology Seismological } \\
\text { Laboratory (Caltech), United States Geological Survey (USGS) } \\
\text { Classification: Domain-specific Integration Interface }\end{array}$ \\
\hline $\begin{array}{l}\text { Common Biometric Exchange } \\
\text { Formats Framework (CBEFF) }\end{array}$ & $\begin{array}{l}\text { Description: The Common Biometric Exchange Formats } \\
\text { Framework (CBEFF) describes the data elements necessary for } \\
\text { biometric data interchange among proprietary application } \\
\text { programs. It describes a set of data elements necessary to } \\
\text { support biometric technologies in a common way. These data } \\
\text { elements can be placed in a single file used to exchange } \\
\text { biometric information between different system components or } \\
\text { between systems themselves. The result promotes } \\
\text { interoperability of biometric-based application programs and } \\
\text { systems developed by different vendors by allowing biometric } \\
\text { data interchange. Specifically, ANSI International Committee } \\
\text { for Information Technology Standards (INCITS) } 398 \text { supports } \\
\text { multiple biometric data types (e.g., fingerprint, face, and voice } \\
\text { recognition.) and/or multiple biometric data blocks of the same } \\
\text { biometric type. It also defines biometric data objects for use } \\
\text { within smart cards and other tokens and describes common } \\
\text { fields for biometric features and the validity period [ANSI } \\
\text { 2010]. } \\
\text { Standard Type: ANSI INCITS 398-2008 } \\
\text { Organization: American National Standards Institute (ANSI) } \\
\text { Classification: Domain-specific Integration Interface }\end{array}$ \\
\hline $\begin{array}{l}\text { Common Intrusion Detection } \\
\text { Signatures Standard (CIDSS) }\end{array}$ & $\begin{array}{l}\text { Description: The purpose of the Common Intrusion Detection } \\
\text { Signatures Standard (CIDSS) is to define a common data format } \\
\text { for storing signatures from different intrusion detection systems. } \\
\text { CIDSS describes a common data format to represent information } \\
\text { contained in signatures of intrusion detection systems, and } \\
\text { explains the rationale for using this common format. The } \\
\text { proposed format is a dialect of the Extensible Markup Language } \\
\text { (XML) [OASIS 2010a]. } \\
\text { Standard Type: CIDSS Version } 05 \\
\text { Organization: CIDSS Development Group } \\
\text { Classification: Domain-specific Integration Interface }\end{array}$ \\
\hline
\end{tabular}




\begin{tabular}{|c|c|}
\hline $\begin{array}{l}\text { Critical Infrastructure Protection } \\
\text { Initiative (CIPI) }\end{array}$ & $\begin{array}{l}\text { Description: The Open GIS Consortium (OGC) Critical } \\
\text { Infrastructure Protection Initiative (CIPI) is an OGC } \\
\text { Interoperability Initiative designed to test the application of } \\
\text { interoperable technology to meet Critical Infrastructure } \\
\text { Detection, Prevention, Planning, Response, and Recovery } \\
\text { challenges. The Critical Infrastructure Protection Initiative } \\
\text { Phase 1, Requirement Set } 2 \text { (CIPI-1.2) is a pilot project that } \\
\text { leverages the success of previous and ongoing OGC initiatives } \\
\text { to improve interoperability across communities that need to } \\
\text { collaborate to detect, prevent, plan for, respond to, and recover } \\
\text { from natural and human threats to telecommunications, water } \\
\text { resources, oil and gas, government, transportation, emergency } \\
\text { response, electric power and health services infrastructure. A } \\
\text { collaborative effort, CIPI is being conducted in coordination } \\
\text { with federal, state, local government, commercial, and non- } \\
\text { government sponsors. CIPI will also identify requirements for } \\
\text { new specifications to advance plug and play interoperability for } \\
\text { critical infrastructure protection. The work on CIPI 1.2 has } \\
\text { produced Draft Interoperability Reports [OGC 2010]. } \\
\text { Standard Type: CIPI, Phase 1.2 } \\
\text { Organization: Open GIS Consortium (OGC) } \\
\text { Classification: Operational Guidelines }\end{array}$ \\
\hline $\begin{array}{l}\text { Emergency Alert System-Common } \\
\text { Alerting Protocol (EAS-CAP) } \\
\text { Implementation Guide }\end{array}$ & $\begin{array}{l}\text { Description: Public warnings intended for transmission over the } \\
\text { Emergency Alert System (EAS) can be encoded in Common } \\
\text { Alerting Protocol (CAP) messages in various ways. The EAS- } \\
\text { CAP Industry Group (ECIG) Implementation Guide (Version } \\
\text { 1.0) has been compiled in light of the draft OASIS CAP v1.2 } \\
\text { specification and the Integrated Public Alert and Warning } \\
\text { System (IPAWS) CAP-EAS Profile v1.0, as well as the results } \\
\text { of a public comment period on the prior draft Implementation } \\
\text { Guide. The guide is intended to further reduce areas of } \\
\text { uncertainty in how an alert will be presented to the public via } \\
\text { CAP-EAS, so that originators and distributors of alerts can } \\
\text { deliver the intended message to the public, regardless of the } \\
\text { vendors or platforms involved [ECIG 2010]. } \\
\text { Standard Type: ECIG-IG-1.0 } \\
\text { Organization: EAS-CAP Industry Group (ECIG) } \\
\text { Classification: Operational Guidelines }\end{array}$ \\
\hline Emergency Management Standard & $\begin{array}{l}\text { Description: The Emergency Management Standard by the } \\
\text { Emergency Management Accreditation Program (EMAP) is } \\
\text { designed as a tool for continuous improvement as part of a } \\
\text { voluntary accreditation process for local and state emergency } \\
\text { management programs. EMAP makes no representation or } \\
\text { guarantee as to the efficacy of any program as a result of use of } \\
\text { or compliance with the standards contained herein. EMAP } \\
\text { makes no guarantee or warranty as to the completeness of } \\
\text { information in this document, and EMAP expressly disclaims } \\
\text { liability for any personal injury or damages of any nature }\end{array}$ \\
\hline
\end{tabular}




\begin{tabular}{|c|c|}
\hline & $\begin{array}{l}\text { resulting from the publication, use of, or reliance on this } \\
\text { document. Standard language has been developed through a } \\
\text { series of collaborative workshops and committee and } \\
\text { commission meetings [EMAP 2010]. } \\
\text { Standard Type: EMAP Standard, September } 2007 \\
\text { Organization: Emergency Management Accreditation Program } \\
\text { (EMAP) } \\
\text { Classification: Domain-specific Integration Interface }\end{array}$ \\
\hline $\begin{array}{l}\text { FEMA Comprehensive Preparedness } \\
\text { Guide }\end{array}$ & $\begin{array}{l}\text { Description: The Federal Emergency Management Agency } \\
\text { (FEMA) Comprehensive Preparedness Guide provides general } \\
\text { guidelines on developing Emergency Operations Plans (EOPs). } \\
\text { It promotes a common understanding of the fundamentals of } \\
\text { planning and decision making to help emergency planners } \\
\text { examine a hazard and produce integrated, coordinated, and } \\
\text { synchronized plans. This Guide helps emergency managers in } \\
\text { State, Territorial, Local, and Tribal governments in their efforts } \\
\text { to develop and maintain a viable all-hazard EOP [FEMA } \\
\text { 2010a]. } \\
\text { Standard Type: CPG } 101 \\
\text { Organization: Federal Emergency Management Agency } \\
\text { (FEMA) } \\
\text { Classification: Operational Guidelines }\end{array}$ \\
\hline $\begin{array}{l}\text { Global Justice XML Data Model } \\
\text { (GJXDM) }\end{array}$ & $\begin{array}{l}\text { Description: The Global Justice XML Data Model (GJXDM) is } \\
\text { an XML standard designed specifically for criminal justice } \\
\text { information exchanges, providing law enforcement, public } \\
\text { safety agencies, prosecutors, public defenders, and the judicial } \\
\text { branch with a tool to effectively share data and information in a } \\
\text { timely manner. There are three primary parts to the GJXDM: the } \\
\text { Data Dictionary (identifying content and meaning), the Data } \\
\text { Model (defining structure and organization), and the Component } \\
\text { Reuse Repository [OJP 2010]. } \\
\text { Standard Type: Global JXDM Version 3.0.3 } \\
\text { Organization: U.S. Department of Justice (DOJ) } \\
\text { Classification: Domain-specific Integration Interface }\end{array}$ \\
\hline $\begin{array}{l}\text { Incident Command System (ICS) } \\
\text { Model Procedures Guide for } \\
\text { Incidents Involving Structural Fire } \\
\text { Fighting, High Rise, Multi Casualty, } \\
\text { Highway, \& Managing Large-Scale } \\
\text { Incidents Using NIMS-ICS }\end{array}$ & $\begin{array}{l}\text { Description: This manual combines the information from four } \\
\text { existing National Incident Management System Consortium } \\
\text { (NIMSC) Model Procedures Guides, plus new information on } \\
\text { managing large-scale incidents, into one comprehensive, NIMS- } \\
\text { compliant book. As with all NIMSC model procedures, this } \\
\text { information was developed and approved by a broad group of } \\
\text { national experts on these topics. The manual includes basic } \\
\text { information on the National Incident Management System } \\
\text { (NIMS) ICS and then detailed information on how to apply it to } \\
\text { structure fires, high-rise fires, major EMS incidents, roadway } \\
\text { incidents, and large-scale incidents of all types. This includes } \\
\text { concepts such as unified command, area command, joint } \\
\text { operations centers (JOC), multi-agency coordination centers } \\
\text { (MACC) and much more. This is the definitive text on the }\end{array}$ \\
\hline
\end{tabular}




\begin{tabular}{|c|c|}
\hline & $\begin{array}{l}\text { application of NIMS ICS to common types of emergency } \\
\text { incidents [NIMCS 2010a]. } \\
\text { Standard Type: Incident Command System (ICS) Model } \\
\text { Procedures Guide for Incidents Involving Structural Fire } \\
\text { Fighting, High Rise, Multi Casualty, Highway, \& Managing } \\
\text { Large-Scale Incidents Using NIMS-ICS, Book 1 - First Edition } \\
\text { Organization: National Incident Management System } \\
\text { Consortium (NIMSC) } \\
\text { Classification: Operational Guidelines }\end{array}$ \\
\hline $\begin{array}{l}\text { Incident Command System (ICS) } \\
\text { Model Procedures Guide for Special } \\
\text { Operations - Incidents Involving } \\
\text { Hazardous Materials/WMD, } \\
\text { Structural Collapse, Wildland, and } \\
\text { Managing Large-Scale Incidents } \\
\text { Using NIMS-ICS }\end{array}$ & $\begin{array}{l}\text { Description: This manual combines the information from three } \\
\text { existing National Incident Management System Consortium } \\
\text { (NIMSC) Model Procedures Guides, plus new information on } \\
\text { managing large-scale incidents, into one comprehensive, NIMS- } \\
\text { compliant book. As with all NIMSC model procedures, this } \\
\text { information was developed and approved by a broad group of } \\
\text { national experts on these topics. The manual includes basic } \\
\text { information on NIMS Incident Command System (ICS) and then } \\
\text { detailed information on how to apply it to wildland, hazardous } \\
\text { materials, urban search and rescue structural collapse, and large- } \\
\text { scale incidents of all types. This includes concepts such as } \\
\text { unified command, area command, joint operations centers } \\
\text { (JOC), multi-agency coordination centers (MACC), and much } \\
\text { more [NIMCS 2010b]. } \\
\text { Standard Type: Special Operations - Incidents Involving } \\
\text { Hazardous Materials/WMD, Structural Collapse, Wildland, and } \\
\text { Managing Large-Scale Incidents Using NIMS-ICS, Book } 2 \text { - } \\
\text { First Edition } \\
\text { Organization: National Incident Management System } \\
\text { Consortium (NIMSC) } \\
\text { Classification: Operational Guidelines }\end{array}$ \\
\hline $\begin{array}{l}\text { Incident Object Description and } \\
\text { Exchange Format (IODEF) }\end{array}$ & $\begin{array}{l}\text { Description: The Incident Object Description Exchange Format } \\
\text { (IODEF) is a format for representing computer security } \\
\text { information commonly exchanged between Computer Security } \\
\text { Incident Response Teams (CSIRTs). It provides an XML } \\
\text { representation for conveying incident information across } \\
\text { administrative domains between parties that have an operational } \\
\text { responsibility of remediation or a watch-and-warning over a } \\
\text { defined constituency. The data model encodes information } \\
\text { about hosts, networks, and the services running on these } \\
\text { systems; attack methodology and associated forensic evidence; } \\
\text { impact of the activity; and limited approaches for documenting } \\
\text { workflow [OASIS 2010a]. } \\
\text { Standard Type: Industry specification } \\
\text { Organization: Internet Engineering Task Force (IETF) } \\
\text { Extended Incident Handling (INCH) Working Group } \\
\text { Classification: Domain-specific Integration Interface }\end{array}$ \\
\hline $\begin{array}{l}\text { Intrusion Detection Message } \\
\text { Exchange Format (IDMEF) }\end{array}$ & $\begin{array}{l}\text { Description: The purpose of the Intrusion Detection Message } \\
\text { Exchange Format (IDMEF) is to define data formats and }\end{array}$ \\
\hline
\end{tabular}




\begin{tabular}{|c|c|}
\hline & $\begin{array}{l}\text { exchange procedures for sharing information of interest to } \\
\text { intrusion detection and response systems, and to the } \\
\text { management systems, which may need to interact with them. } \\
\text { The IDMEF data model is an object-oriented representation of } \\
\text { the alert data sent to intrusion detection managers by intrusion } \\
\text { detection analyzers. The data model defines support classes that } \\
\text { accommodate the differences in data sources among analyzers. } \\
\text { In particular, the notions of source and target for the alert are } \\
\text { represented by the combination of Node, Process, Service, and } \\
\text { User classes [OASIS 2010a]. } \\
\text { Standard Type: IDMEF } \\
\text { Organization: Internet Engineering Task Force (IETF) } \\
\text { Intrusion Detection Exchange Format Working Group } \\
\text { Classification: Domain-specific Integration Interface }\end{array}$ \\
\hline $\begin{array}{l}\text { Managing Hazardous Material } \\
\text { Incidents (MHMIs) }\end{array}$ & $\begin{array}{l}\text { Description: The Managing Hazardous Material Incidents } \\
\text { (MHMIs) series was developed to provide emergency medical } \\
\text { services (EMS) personnel and hospital emergency departments } \\
\text { (EDs) with the necessary guidance to plan for, and improve their } \\
\text { ability to respond to, incidents that involve human exposure to } \\
\text { hazardous materials. The guidelines inform emergency } \\
\text { personnel how to appropriately decontaminate, treat, and } \\
\text { recommend follow-up care to exposed persons, as well as take } \\
\text { measures to protect themselves. The MHMI series contain } 3 \\
\text { volumes: “Emergency medical services: A planning guide for } \\
\text { the management of contaminated patients;" "Hospital } \\
\text { emergency departments: A planning guide for the management } \\
\text { of contaminated patients;” and “Medical management guidelines } \\
\text { (MMGs) for acute chemical exposures" [ATSDR 2010]. } \\
\text { Standard Type: ATSDR MHMIs Version 2001 } \\
\text { Organization: The Agency for Toxic Substances and Disease } \\
\text { Registry (ATSDR) } \\
\text { Classification: Operational Guidelines }\end{array}$ \\
\hline $\begin{array}{l}\text { Mass Casualty Event Preparedness } \\
\text { and Response }\end{array}$ & $\begin{array}{l}\text { Description: This document is an interim planning guidance for } \\
\text { preparedness and response to a mass casualty event resulting } \\
\text { from terrorist use of explosives. It includes a description of } \\
\text { system-wide and discipline-specific challenges as well as } \\
\text { recommended solutions to address these challenges. The } \\
\text { proposed solutions for the discipline-specific challenges have } \\
\text { been incorporated into easy to use templates that can assist } \\
\text { various disciplines in managing surge needs for injuries. [CDC } \\
\text { 2010a]. } \\
\text { Standard Type: Government document } \\
\text { Organization: The Centers for Disease Control and Prevention } \\
\text { (CDC) } \\
\text { Classification: Operational Guidelines }\end{array}$ \\
\hline $\begin{array}{l}\text { Model Procedures Guide for } \\
\text { Highway Incidents }\end{array}$ & $\begin{array}{l}\text { Description: Model Procedures Guide for Highway Incidents is } \\
\text { a document that guides application of the Incident Management } \\
\text { System (IMS) to events occurring on these high-volume }\end{array}$ \\
\hline
\end{tabular}




\begin{tabular}{|c|c|}
\hline & $\begin{array}{l}\text { roadways. The Guide addresses command structures for } \\
\text { potential events ranging from parades to hazmat spills. Its idea is } \\
\text { that the IMS is adaptable enough to handle incidents as small as } \\
\text { a single-car breakdown and as large as a major winter storm. } \\
\text { The guide discusses the factors involved in: providing } \\
\text { emergency services and unblocking traffic as quickly as } \\
\text { possible; protecting incident responders and those under their } \\
\text { care from moving vehicles; protecting other motorists, } \\
\text { passengers and cargo from incident hazards; facilitating the } \\
\text { movement of emergency vehicles to and from the scene; and } \\
\text { facilitating traffic flow past the incident and throughout the area } \\
\text { [DOT 2010]. } \\
\text { Standard Type: Government document } \\
\text { Organization: National Fire Service Incident Management } \\
\text { System Consortium (NFSIMSC), U.S. Department of } \\
\text { Transportation } \\
\text { Classification: Operational Guidelines }\end{array}$ \\
\hline $\begin{array}{l}\text { National Emergency } \\
\text { Communications Plan }\end{array}$ & $\begin{array}{l}\text { Description: The National Emergency Communications Plan } \\
\text { (NECP) is a strategic plan that sets goals and identifies key } \\
\text { national priorities to enhance governance, planning, technology, } \\
\text { training and exercises, and disaster communications capabilities. } \\
\text { The NECP provides recommendations including milestones to } \\
\text { help emergency response providers and relevant government } \\
\text { officials make measurable improvements in emergency } \\
\text { communications over the next three years [DHS 2010b]. } \\
\text { Standard Type: NEPC, July } 2008 \\
\text { Organization: U.S. Department of Homeland Security (DHS) } \\
\text { Classification: Operational Guidelines }\end{array}$ \\
\hline $\begin{array}{l}\text { National Incident Management } \\
\text { System (NIMS) }\end{array}$ & $\begin{array}{l}\text { Description: The National Incident Management System } \\
\text { (NIMS) provides a systematic, proactive approach to guide } \\
\text { departments and agencies at all levels of government, } \\
\text { nongovernmental organizations, and the private sector to work } \\
\text { seamlessly to prevent, protect against, respond to, recover from, } \\
\text { and mitigate the effects of incidents, regardless of cause, size, } \\
\text { location, or complexity, in order to reduce the loss of life and } \\
\text { property and harm to the environment [FEMA 2010b]. } \\
\text { Standard Type: National Incident Management System, } \\
\text { December 2008 } \\
\text { Organization: U.S. Department of Homeland Security (DHS) } \\
\text { Classification: Operational Guidelines }\end{array}$ \\
\hline National Preparedness Guidelines & $\begin{array}{l}\text { Description: The Guidelines, including the supporting Target } \\
\text { Capabilities List, supersedes the Interim National Preparedness } \\
\text { Goal and defines what it means for the Nation to be prepared for } \\
\text { all hazards. There are four critical elements of the Guidelines: } \\
\text { National Preparedness Vision, National Planning Scenarios, } \\
\text { Universal Task List (UTL), and Target Capabilities List (TCL) } \\
\text { [FEMA 2010c]. } \\
\text { Standard Type: National Preparedness Guidelines, September }\end{array}$ \\
\hline
\end{tabular}




\begin{tabular}{|c|c|}
\hline & $\begin{array}{l}2007 \\
\text { Organization: U.S. Department of Homeland Security (DHS) } \\
\text { Classification: Operational Guidelines }\end{array}$ \\
\hline National Response Framework & $\begin{array}{l}\text { Description: The National Response Framework presents the } \\
\text { guiding principles that enable all response partners to prepare } \\
\text { for and provide a unified national response to disasters and } \\
\text { emergencies - from the smallest incident to the largest } \\
\text { catastrophe. The Framework establishes a comprehensive, } \\
\text { national, all-hazards approach to domestic incident response } \\
\text { [FEMA 2010d]. } \\
\text { Standard Type: National Response Framework, January } 2008 \\
\text { Organization: U.S. Department of Homeland Security (DHS) } \\
\text { Classification: Operational Guidelines }\end{array}$ \\
\hline $\begin{array}{l}\text { National Strategy for Homeland } \\
\text { Security }\end{array}$ & $\begin{array}{l}\text { Description: The National Strategy for Homeland Security } \\
\text { guides, organizes, and unifies our Nation's homeland security } \\
\text { efforts. The } 2008 \text { Strategic Plan serves to focus the } \\
\text { Department's mission and sharpen operational effectiveness, } \\
\text { particularly in delivering services in support of Department- } \\
\text { wide initiatives and the other mission goals. It identifies the } \\
\text { goals and objectives by which we continually assess our } \\
\text { performance. The Department uses performance measures at all } \\
\text { levels to monitor our strategic progress and program success. } \\
\text { This process also keeps the Department’s priorities aligned, } \\
\text { linking programs and operations to performance measures, } \\
\text { mission goals, resource priorities, and strategic objectives [DHS } \\
\text { 2010c]. } \\
\text { Standard Type: National Strategy for Homeland Security, } \\
\text { September 16, 2008 } \\
\text { Organization: U.S. Department of Homeland Security (DHS) } \\
\text { Classification: Operational Guidelines }\end{array}$ \\
\hline $\begin{array}{l}\text { New Guide for School Preparedness } \\
\text { and All Hazard Response }\end{array}$ & $\begin{array}{l}\text { Description: The guide covers concepts, principles, and best } \\
\text { practices for all-hazards integrated emergency management } \\
\text { programs in preparedness, prevention, mitigation, response, and } \\
\text { recovery for schools and school districts in preparation and } \\
\text { response to a natural or man-caused incident [ASTM 2010]. } \\
\text { Standard Type: ASTM WK8908 (Work Item) } \\
\text { Organization: ASTM International } \\
\text { Classification: Operational Guidelines }\end{array}$ \\
\hline $\begin{array}{l}\text { Preparing for a Terrorist Bombing: } \\
\text { A Common Sense Approach }\end{array}$ & $\begin{array}{l}\text { Description: This document focuses on common sense } \\
\text { principles that will be useful in a bombing event [CDC 2010b]. } \\
\text { Standard Type: Government document } \\
\text { Organization: The Centers for Disease Control and Prevention } \\
\text { (CDC) } \\
\text { Classification: Operational Guidelines }\end{array}$ \\
\hline
\end{tabular}




\begin{tabular}{|c|c|}
\hline Really Simple Syndication (RSS) & $\begin{array}{l}\text { Description: Really Simple Syndication (RSS) is a family of } \\
\text { web feed formats used to publish frequently updated works, } \\
\text { such as blog entries, news headlines, audio, and video, in a } \\
\text { standardized format. An RSS document includes full or } \\
\text { summarized text, plus metadata such as publishing dates and } \\
\text { authorship. Web feeds benefit publishers by letting them } \\
\text { syndicate content automatically. They benefit readers who want } \\
\text { to subscribe to timely updates from favored websites or to } \\
\text { aggregate feeds from many sites into one place [RSSBOARD } \\
\text { 2010]. } \\
\text { Standard Type: RSS } 2.0 \\
\text { Organization: RSS Advisory Board } \\
\text { Classification: Domain-specific Integration Interface }\end{array}$ \\
\hline $\begin{array}{l}\text { Standard Classification for Search } \\
\text { and Rescue Dog Crew/Teams }\end{array}$ & $\begin{array}{l}\text { Description: The Standard Classification for Search and Rescue } \\
\text { Dog Crew/Teams covers the aid of search and rescue managers } \\
\text { in ordering resources for search and rescue incidents and to aid } \\
\text { dog handlers in communicating the types of tasked for which } \\
\text { they and their dogs have trained. This classification is intended } \\
\text { as a supplement to the resource typing specifications of the } \\
\text { Incident Command System and specifically as a means of typing } \\
\text { search and rescue dog resources. This classification is suitable } \\
\text { for classifying dog resources for a wide variety of emergency } \\
\text { management purposes including both search and rescue and law } \\
\text { enforcement incidents [ASTM 2010]. } \\
\text { Standard Type: ASTM F1848-98 (2005) } \\
\text { Organization: ASTM International } \\
\text { Classification: Operational Guidelines }\end{array}$ \\
\hline $\begin{array}{l}\text { Standard for Installation, } \\
\text { Maintenance, and Use of Emergency } \\
\text { Services Communications Systems }\end{array}$ & $\begin{array}{l}\text { Description: The Standard for Installation, Maintenance, and } \\
\text { Use of Emergency Services Communications Systems covers } \\
\text { the installation, performance, operation, and maintenance of } \\
\text { public emergency services communications systems and } \\
\text { facilities. It is not intended as a design specification manual or } \\
\text { an instruction manual. The standard covers systems that receive } \\
\text { alarms from the public, e.g., 9-1-1 services systems and } \\
\text { communications centers, and retransmits those alarms to } \\
\text { response agencies. It also provides requirements for dispatching } \\
\text { systems and establishes a level of performance and the quality of } \\
\text { installations for emergency communication systems. Elements } \\
\text { of these systems may include communications centers, signal } \\
\text { wiring, emergency response facilities, operations centers, } \\
\text { telephones, dispatching systems, computer-aided dispatching, } \\
\text { and public alerting systems. Other operations covered under this } \\
\text { standard include system testing, record keeping, network } \\
\text { security, and redundancy [NFPA 2010]. } \\
\text { Standard Type: NFPA 1221-2010 } \\
\text { Organization: The National Fire Protection Association } \\
\text { (NFPA) } \\
\text { Classification: Operational Guidelines }\end{array}$ \\
\hline
\end{tabular}




\begin{tabular}{|c|c|}
\hline $\begin{array}{l}\text { Standard Guide for Developing a } \\
\text { Hazardous Materials Training } \\
\text { Curriculum for Initial Response } \\
\text { Personnel }\end{array}$ & $\begin{array}{l}\text { Description: This guide summarizes the typical contents of a } \\
\text { course to aid emergency response team training organizations in } \\
\text { selecting important subjects for inclusion in existing or new } \\
\text { training programs. It covers a format for a hazardous materials } \\
\text { spill initial response team training curriculum [ASTM 2010]. } \\
\text { Standard Type: F1011 - } 07 \\
\text { Organization: ASTM International } \\
\text { Classification: Operational Guideline }\end{array}$ \\
\hline $\begin{array}{l}\text { Standard Guide for Using the } \\
\text { Incident Command System } \\
\text { Framework in Managing Search and } \\
\text { Rescue Operations }\end{array}$ & $\begin{array}{l}\text { Description: This Standard Guide for Using the Incident } \\
\text { Command System Framework in Managing Search and Rescue } \\
\text { Operations covers the use of the Incident Command System } \\
\text { (ICS), as developed in the National Incident Management } \\
\text { System (NIMS) in 2004, as the management framework for } \\
\text { search and rescue (SAR) operations. Except as otherwise } \\
\text { specified herein, the methods and requirements of this standard } \\
\text { also include NIMS, ICS, and National Response Framework } \\
\text { (NRF) requirements, when required, for search and rescue } \\
\text { personnel that deploy within the United States of America. The } \\
\text { ICS may be used outside of the United States for managing SAR } \\
\text { operations, users of this standard need to be aware of other } \\
\text { incident management requirements, guidelines, policies, } \\
\text { procedures, and protocols within the area of ICS SAR operations } \\
\text { [ASTM 2010]. } \\
\text { Standard Type: ASTM F1422 - 08 } \\
\text { Organization: ASTM International } \\
\text { Classification: Operational Guidelines }\end{array}$ \\
\hline $\begin{array}{l}\text { Standard on Disaster/Emergency } \\
\text { Management and Business } \\
\text { Continuity Programs }\end{array}$ & $\begin{array}{l}\text { Description: This standard establishes a common set of criteria } \\
\text { for disaster/emergency management and business continuity } \\
\text { programs. Specifically, this standard provides } \\
\text { disaster/emergency management and business continuity } \\
\text { programs the criteria to assess current programs or to develop, } \\
\text { implement, and maintain aspects for prevention, mitigation, } \\
\text { preparation, response, and recovery from emergencies. This } \\
\text { standard applies to public, nongovernmental, and private entities } \\
\text { [NFPA 2010]. } \\
\text { Standard Type: NFPA } 1600 \text { (2007) } \\
\text { Organization: National Fire Protection Association (NFPA) } \\
\text { Classification: Operational Guidelines }\end{array}$ \\
\hline $\begin{array}{l}\text { Standard on Emergency Services } \\
\text { Incident Management System }\end{array}$ & $\begin{array}{l}\text { Description: This standard establishes the minimum } \\
\text { requirements for an incident management system to be used by } \\
\text { emergency services to manage all incidents/planned events. } \\
\text { Requirements are established for operating systems, } \\
\text { implementation, and communications. Furthermore, the standard } \\
\text { provides a description of key positions and roles within the } \\
\text { incident management system, including the functions of the } \\
\text { Incident Commander, Command Staff, Operations, Planning, } \\
\text { Logistics, and Finance/Administration. The standard also } \\
\text { addresses requirements for multi-agency coordination and }\end{array}$ \\
\hline
\end{tabular}




\begin{tabular}{|c|c|}
\hline & $\begin{array}{l}\text { training and staffing for Incident Management Teams [NFPA } \\
\text { 2010]. } \\
\text { Standard Type: NFPA } 1561 \text { (2008) } \\
\text { Organization: National Fire Protection Association (NFPA) } \\
\text { Classification: Operational Guidelines }\end{array}$ \\
\hline $\begin{array}{l}\text { Standard on Fire Department } \\
\text { Occupational Safety and Health } \\
\text { Program }\end{array}$ & $\begin{array}{l}\text { Description: The Standard on Fire Department Occupational } \\
\text { Safety and Health Program standard contains minimum } \\
\text { requirements for a fire-service-related occupational safety and } \\
\text { health program. The standard specifies safety requirements for } \\
\text { those members involved in rescue, fire suppression, emergency } \\
\text { medical services, hazardous materials operations, special } \\
\text { operations, and related activities. It covers everything from } \\
\text { training, vehicles, and equipment to protective clothing, } \\
\text { emergency operations, and incident stress [NFPA 2010]. } \\
\text { Standard Type: NFPA } 1500 \text { - } 2007 \\
\text { Organization: National Fire Protection Association (NFPA) } \\
\text { Classification: Operational Guidelines }\end{array}$ \\
\hline $\begin{array}{l}\text { Tsunami Warning Markup Language } \\
\text { (TWML), Cyclone Warning Markup } \\
\text { Language (CWML) }\end{array}$ & $\begin{array}{l}\text { Description: The goal of the Tsunami Warning Markup } \\
\text { Language (TWML) and the Cyclone Warning Markup Language } \\
\text { (CWML) is to facilitate various kinds of automated processing, } \\
\text { such as rapid dissemination to people in affected areas, } \\
\text { aggregation of warning information, and interoperability with } \\
\text { geospatial systems through the use of Geography Markup } \\
\text { Language (GML) elements. The languages are also designed to } \\
\text { be used in conjunction with OASIS standards such as the } \\
\text { Emergency Data eXchange Language Distribution Element } \\
\text { (EDXL-DE) and the Common Alerting Protocol (CAP) [OASIS } \\
\text { 2010b]. } \\
\text { Standard Type: CWML Version 1.0; TWML Draft } \\
\text { Organization: National ICT Australia (NICTA) } \\
\text { Classification: Domain-specific Integration Interface }\end{array}$ \\
\hline $\begin{array}{l}\text { Vehicular Emergency Data Set } \\
\text { (VEDS) }\end{array}$ & $\begin{array}{l}\text { Description: The Vehicular Emergency Data Set (VEDS) is an } \\
\text { XML-based data standard that determines useful and critical } \\
\text { elements needed to prove an efficient emergency response to } \\
\text { vehicular emergency incidents. The Protocol identifies crash and } \\
\text { medical data elements [OASIS 2010b]. } \\
\text { Standard Type: VEDS Version } 2.0 \\
\text { Organization: ComCARE Alliance } \\
\text { Classification: Domain-specific Integration Interface }\end{array}$ \\
\hline
\end{tabular}




\subsubsection{Conceptual Modeling Standards}

\begin{tabular}{|c|c|}
\hline Standard Title & Overview \\
\hline $\begin{array}{l}\text { Discrete Event System Specification } \\
\text { (DEVS) }\end{array}$ & $\begin{array}{l}\text { Description: DEVS is a systems-theoretic approach to } \\
\text { modeling. More specifically, it is state-centered formalism. A } \\
\text { system consists of interconnected subsystems. A subsystem is a } \\
\text { system. Leaf systems (atomic DEVSes) are state machines. } \\
\text { DEVS can be viewed as a framework unifying a number of } \\
\text { other formalisms in a consistent, systems theoretic, state } \\
\text { centered fashion [DEVS 2011]. } \\
\text { Standard Type: Specification } \\
\text { Organization: Simulation Interoperability Standards } \\
\text { Organization (SISO); Society for Modeling and Computer } \\
\text { Simulation International (SCS) } \\
\text { Classification: Domain-specific integration interface }\end{array}$ \\
\hline $\begin{array}{l}\text { Systems Modeling Language } \\
(\text { SysML) }\end{array}$ & $\begin{array}{l}\text { Description: SysML is a general purpose modeling language for } \\
\text { systems engineering applications. It is a dialect of UML, the } \\
\text { industry standard for modeling software-intensive systems. It } \\
\text { supports the specification, analysis, design, verification and } \\
\text { validation of a broad range of systems and systems-of-systems. } \\
\text { These systems may include hardware, software, information, } \\
\text { processes, personnel, and facilities [OMG 2011]. } \\
\text { Standard Type: SysML } 1.2 \\
\text { Organization: Object Management Group, Inc. (OMG) } \\
\text { Classification: Document format }\end{array}$ \\
\hline Unified Modeling Language (UML) & $\begin{array}{l}\text { Description: A graphical language for visualizing, specifying, } \\
\text { constructing and documenting the artifacts of a software- } \\
\text { intensive system. The UML offers a standard way to write a } \\
\text { system's blueprints, including conceptual things such as } \\
\text { business processes and system functions, as well as concrete } \\
\text { things such as programming language statements, database } \\
\text { schemas, and reusable software components [ANSI 2011c]. } \\
\text { Standard Type: UML 2.0, UML 2.1.1; UML 2.1.2; UML 2.2; } \\
\text { UML 2.3; ISO/IEC 19501:2004 } \\
\text { Organization: ISO; ANSI; Object Management Group, Inc. } \\
\text { (OMG) } \\
\text { Classification: Document format }\end{array}$ \\
\hline
\end{tabular}

\subsubsection{Distributed Simulation Standards}

\begin{tabular}{|l|l|}
\hline \multicolumn{1}{|c|}{ Standard Title } & \multicolumn{1}{c|}{ Overview } \\
\hline Distributed Interactive Simulation & $\begin{array}{l}\text { Description: Distributed Interactive Simulation (DIS) is a } \\
\text { government/industry initiative to define an infrastructure for } \\
\text { linking simulations of various types at multiple locations to } \\
\text { create realistic, complex, virtual worlds for the simulation of }\end{array}$ \\
\hline
\end{tabular}




\begin{tabular}{|c|c|}
\hline & $\begin{array}{l}\text { highly interactive activities. A series of IEEE standards to } \\
\text { support information exchange between simulation applications } \\
\text { participating in the DIS environment are defined. IEEE Std } \\
1278.1 \text { defines the format and semantics of data messages, also } \\
\text { known as Protocol Data Units (PDUs), that are exchanged } \\
\text { between simulation applications and simulation management. } \\
\text { IEEE Std } 1278.2 \text { defines the communication services required to } \\
\text { support the message exchange described in IEEE Std 1278.1. } \\
\text { IEEE 1278-3 provides guidelines for establishing a DIS } \\
\text { exercise, managing the exercise, and providing proper feedback. } \\
\text { IEEE 1278-4 establishes guidelines for the verification, } \\
\text { validation, and accreditation (VV\&A) of Distributed Interactive } \\
\text { Simulation (DIS) exercises [IHS 2011a]. } \\
\text { Standard Type: IEEE 1278-1993, IEEE 1278.1-1995, IEEE } \\
\text { 1278.1A-1998, IEEE-1278.2-1995, IEEE 1278.3-1996, IEEE } \\
\text { 1278.4-1997 } \\
\text { Organization: IEEE; IHS, Inc. } \\
\text { Classification: Domain-specific integration interface }\end{array}$ \\
\hline $\begin{array}{l}\text { Extensible Modeling and Simulation } \\
\text { Framework (XMSF) }\end{array}$ & $\begin{array}{l}\text { Description: The Extensible Modeling and Simulation } \\
\text { Framework (XMSF) is defined as a set of Web-based } \\
\text { technologies and services, applied within an extensible } \\
\text { framework, that enables a new generation of modeling \& } \\
\text { simulation (M\&S) applications to emerge, develop and } \\
\text { interoperate [DODCCRP 2004]. XMSF provides a framework } \\
\text { which allows both Department of Defense (DoD) and non-DoD } \\
\text { Modeling and Simulation (M\&S) projects to take advantage of } \\
\text { Web-based technologies. } \\
\text { Standard Type: XMSF 1.0 } \\
\text { Organization: Naval Postgraduate School MOVES Institute; } \\
\text { George Mason University NetLab; Science Applications } \\
\text { International Corporation; Old Dominion University } \\
\text { Classification: Domain-specific integration interface }\end{array}$ \\
\hline High Level Architecture (HLA) & $\begin{array}{l}\text { Description: This standard defines the HLA, its components, } \\
\text { and the rules that outline the responsibilities of HLA federates } \\
\text { and federations to ensure a consistent implementation [IEEE } \\
\text { 2011c]. } \\
\text { Standard Type: IEEE 1516-2000, IEEE 1516.1-2000, 1516.2- } \\
\text { 2000, ANSI/IEEE 1516.3-2003; IEEE 1516.4-2007 } \\
\text { Organization: IEEE/Simulation Interoperability Standards } \\
\text { Organization (SISO); ANSI } \\
\text { Classification: Domain-specific integration interface }\end{array}$ \\
\hline
\end{tabular}




\subsubsection{Selected Geographic Information System (GIS) Standards}

\begin{tabular}{|c|c|}
\hline Standard Title & Overview \\
\hline $\begin{array}{l}\text { CityGML - Exchange and Storage of } \\
\text { Virtual } 3 D \text { City Models }\end{array}$ & $\begin{array}{l}\text { Description: A standard for the representation, storage, and } \\
\text { exchange of virtual 3D city and landscape models. CityGML is } \\
\text { implemented as an application schema of the Geography } \\
\text { Markup Language version 3.1.1. It is based on a rich, general } \\
\text { purpose information model in additional to geometry and } \\
\text { appearance information. For specific domain areas, CityGML } \\
\text { also provides an extension mechanism to enrich the data with } \\
\text { identifiable features under preservation of semantic } \\
\text { interoperability [OGC 2011a]. } \\
\text { Standard Type: OGC 06-057r1; ISO TC211 } \\
\text { Organization: Open Geospatial Consortium, Inc. (OGC) } \\
\text { Classification: Domain-specific integration interface }\end{array}$ \\
\hline $\begin{array}{l}\text { American National Standard for } \\
\text { Information Technology - } \\
\text { Geographical Information Systems - } \\
\text { Spatial Data Standard for Facilities, } \\
\text { Infrastructure, and Environment } \\
\text { (SDSFIE) }\end{array}$ & $\begin{array}{l}\text { Description: This standard provides a means to model and } \\
\text { categorize real-world geographic phenomena of interest to the } \\
\text { Facilities, Infrastructure, and Environment (FIE) Domain(s) into } \\
\text { a set of geographic data that can be represented in a spatial } \\
\text { database and presented to a user in digital form. This SDSFIE } \\
\text { standard is intended to provide the enterprise spatial database } \\
\text { schema to support multiple FIE applications. This National } \\
\text { Standard is applicable to the federal, state, county, and city } \\
\text { agencies; private companies; and any other organizations that } \\
\text { perform AM \& FM functions for facilities and other types of } \\
\text { infrastructure (such as roads, waterways, utility systems, etc,) } \\
\text { and/or perform environmental compliance, restoration, and/or } \\
\text { pollution prevention activities [ANSI 2011a]. } \\
\text { Standard Type: ANSI INCITS 353-2006 } \\
\text { Organization: American National Standards Institute (ANSI); } \\
\text { International Committee for Information Technology Standards } \\
\text { (INCITS) } \\
\text { Classification: Domain-specific integration interface }\end{array}$ \\
\hline $\begin{array}{l}\text { Content Standard for Digital } \\
\text { Geospatial Metadata (CSDGM) }\end{array}$ & $\begin{array}{l}\text { Description: The standard is often referred to as the FGDC } \\
\text { Metadata Standard. The objectives of the standard are to } \\
\text { provide a common set of terminology and definitions for the } \\
\text { documentation of digital geospatial data. The standard } \\
\text { establishes the names of data elements and compound elements } \\
\text { (groups of data elements) to be used for these purposes, the } \\
\text { definitions of these compound elements and data elements, and } \\
\text { information about the values that are to be provided for the data } \\
\text { elements [FGDC 2011a]. } \\
\text { Standard Type: FGDC-STD-001-1998; FGDC-STD-001.1- } \\
\text { 1999; FGDC-STD-001.2-2001 } \\
\text { Organization: Federal Geographic Data Committee (FGDC) } \\
\text { Classification: Domain-specific integration interface }\end{array}$ \\
\hline
\end{tabular}




\begin{tabular}{|c|c|}
\hline $\begin{array}{l}\text { Content Standard for Digital } \\
\text { Geospatial Metadata (CSDGM) - } \\
\text { Extensions for Remote Sensing } \\
\text { Metadata }\end{array}$ & $\begin{array}{l}\text { Description: The standard of Extensions for Remote Sensing } \\
\text { Metadata standard provides a common terminology and set of } \\
\text { definitions for documenting geospatial data obtained from } \\
\text { remote sensing, within the framework of the FGDC Content } \\
\text { Standard for Digital Geospatial Metadata (CSDGM) standard. } \\
\text { The extensions provide a means to use standard FGDC content } \\
\text { to describe geospatial data derived from remote sensing } \\
\text { measurements. This standard is intended to support the } \\
\text { collection and processing of geospatial metadata for data derived } \\
\text { from remote sensing. It is intended to be used by all levels of } \\
\text { government and the private sector [FGDC 2011b]. } \\
\text { Standard Type: FGDC-STD-012-2002 } \\
\text { Organization: The Federal Geographic Data Committee } \\
\text { (FGDC) } \\
\text { Classification: Domain-specific integration interface }\end{array}$ \\
\hline I SWG Standard & $\begin{array}{l}\text { Description: The GeoAPI Standard Working Group (SWG) } \\
\text { aims to create the GeoAPI 3.0 Standard, which will define a set } \\
\text { of Java language interfaces along with an associated test suite, to } \\
\text { provide a standardized, programming language level realization } \\
\text { of some core Open Geospatial Consortium (OGC) } \\
\text { specifications. These interfaces will facilitate the creation of } \\
\text { accurate, coherent, interoperable, and verifiable implementations } \\
\text { of those OGC standards [GEOAPI 2011]. } \\
\text { Standard Type: OGC GeoAPI 3.0 SWG } \\
\text { Organization: OGC } \\
\text { Classification: Domain-specific integration interface }\end{array}$ \\
\hline Geographic Information - Enco & $\begin{array}{l}\text { Description: The standard specifies the requirements for } \\
\text { defining encoding rules to be used for interchange of geographic } \\
\text { data within the ISO } 19100 \text { series of International Standards [ISO } \\
\text { 2011b]. } \\
\text { Standard Type: ISO 19118:2005 } \\
\text { Organization: ISO } \\
\text { Classification: Domain-specific integration interface }\end{array}$ \\
\hline $\begin{array}{l}\text { Geographic information - Location- } \\
\text { based Services - Multimodal Routing } \\
\text { and Navigation }\end{array}$ & $\begin{array}{l}\text { Description: The standard specifies the data types and their } \\
\text { associated operations for the implementation of multimodal } \\
\text { location-based services for routing and navigation. It is designed } \\
\text { to specify web services that may be made available to wireless } \\
\text { devices through web-resident proxy applications, but is not } \\
\text { limited to that environment [ISO 2011b]. } \\
\text { Standard Type: ISO 19134:2007 } \\
\text { Organization: ISO } \\
\text { Classification: Domain-specific integration interface }\end{array}$ \\
\hline $\begin{array}{l}\text { Geographic Information - Location- } \\
\text { based Services - Tracking and } \\
\text { Navigation }\end{array}$ & $\begin{array}{l}\text { Description: ISO 19133:2005 describes the data types, and } \\
\text { operations associated with those types, for the implementation } \\
\text { of tracking and navigation services. It is designed to specify web } \\
\text { services that can be made available to wireless devices through }\end{array}$ \\
\hline
\end{tabular}




\begin{tabular}{|c|c|}
\hline & $\begin{array}{l}\text { web-resident proxy applications, but is not restricted to that } \\
\text { environment [ISO 2011b]. } \\
\text { Standard Type: ISO 19133:2005 } \\
\text { Organization: ISO } \\
\text { Classification: Domain-specific integration interface }\end{array}$ \\
\hline Geographic Information - Portrayal & $\begin{array}{l}\text { Description: The standard defines a schema describing the } \\
\text { portrayal of geographic information in a form understandable by } \\
\text { humans. It includes the methodology for describing symbols and } \\
\text { mapping of the schema to an application schema. It does not } \\
\text { include standardization of cartographic symbols, and their } \\
\text { geometric and functional description [ISO 2011b]. } \\
\text { Standard Type: ISO 19117:2005 } \\
\text { Organization: ISO } \\
\text { Classification: Domain-specific integration interface }\end{array}$ \\
\hline $\begin{array}{l}\text { Geographic Information - } \\
\text { Procedures for Item Registration }\end{array}$ & $\begin{array}{l}\text { Description: ISO 19135:2005 specifies procedures to be } \\
\text { followed in establishing, maintaining and publishing registers of } \\
\text { unique, unambiguous and permanent identifiers, and meanings } \\
\text { that are assigned to items of geographic information. In order to } \\
\text { accomplish this purpose, ISO 19135:2005 specifies elements of } \\
\text { information that are necessary to provide identification and } \\
\text { meaning to the registered items and to manage the registration of } \\
\text { these items [ISO 2011b]. } \\
\text { Standard Type: INCITS/ISO/IEC 19135-2005 } \\
\text { Organization: ISO; International Committee for Information } \\
\text { Technology Standards (INCITS); International Electrotechnical } \\
\text { Commission (IEC) } \\
\text { Classification: Domain-specific integration interface }\end{array}$ \\
\hline $\begin{array}{l}\text { Geographic Information - Schema } \\
\text { for Moving Features }\end{array}$ & $\begin{array}{l}\text { Description: The standard defines a method to describe the } \\
\text { geometry of a feature that moves as a rigid body [ISO 2011b]. } \\
\text { Standard Type: ISO 19141:2008 } \\
\text { Organization: ISO } \\
\text { Classification: Domain-specific integration interface }\end{array}$ \\
\hline Geographic Information - Services & $\begin{array}{l}\text { Description: ISO 19119:2005 identifies and defines the } \\
\text { architecture patterns for service interfaces used for geographic } \\
\text { information, defines its relationship to the Open Systems } \\
\text { Environment model, presents a geographic services taxonomy } \\
\text { and a list of example geographic services placed in the services } \\
\text { taxonomy. It also prescribes how to create a platform-neutral } \\
\text { service specification, how to derive conformant platform- } \\
\text { specific service specifications, and provides guidelines for the } \\
\text { selection and specification of geographic services from both } \\
\text { platform-neutral and platform-specific perspectives [ISO } \\
\text { 2011b]. } \\
\text { Standard Type: INCITS/ISO 19119-2005 } \\
\text { Organization: ISO; International Committee for Information } \\
\text { Technology Standards (INCITS) }\end{array}$ \\
\hline
\end{tabular}




\begin{tabular}{|c|c|}
\hline & Classification: Domain-specific integration interface \\
\hline $\begin{array}{l}\text { Geographic Information - Simple } \\
\text { Feature Access }\end{array}$ & $\begin{array}{l}\text { Description: ISO 19125-1:2004 establishes a common } \\
\text { architecture for geographic information and defines terms to use } \\
\text { within the architecture. It also standardizes names and geometric } \\
\text { definitions for Types for Geometry. INCITS/ISO 19125-2-2004 } \\
\text { specifies an Structured Query Language (SQL) schema that } \\
\text { supports storage, retrieval, query and update of simple } \\
\text { geospatial feature collections via the SQL Call Level Interface } \\
\text { (SQL/CLI) and establishes an architecture for the } \\
\text { implementation of feature tables. INCITS/ISO 19125-2-2004 } \\
\text { defines terms to use within the architecture of geographic } \\
\text { information and defines a simple feature profile of ISO 19107. } \\
\text { In addition, this part of ISO 19125:2004 describes a set of SQL } \\
\text { Geometry Types together with SQL functions on those types. } \\
\text { The Geometry Types and Functions described represent a profile } \\
\text { of ISO 13249-3. INCITS/ISO 19125-2-2004 standardizes the } \\
\text { names and geometric definitions of the SQL Types for } \\
\text { Geometry and the names, signatures and geometric definitions } \\
\text { of the SQL Functions for Geometry [ISO 2011b]. } \\
\text { Standard Type: INCITS/ISO 19125-1-2004 ; INCITS/ISO } \\
\text { 19125-2-2004 } \\
\text { Organization: ISO; International Committee for Information } \\
\text { Technology Standards (INCITS) } \\
\text { Classification: Domain-specific integration interface }\end{array}$ \\
\hline $\begin{array}{l}\text { Geographic Information Framework } \\
\text { Data Standard }\end{array}$ & $\begin{array}{l}\text { Description: The standard establishes common data } \\
\text { requirements for the exchange of National Spatial Data } \\
\text { Infrastructure (NSDI) framework data [FGDC 2011c]. } \\
\text { Standard Type: FGDC-STD-014.0-2008; FGDC-STD-014.1- } \\
\text { 2008; FGDC-STD-014.2-2008; FGDC-STD-014.3-2008; } \\
\text { FGDC-STD-014.4-2008; FGDC-STD-014.5-2008; FGDC-STD- } \\
\text { 014.6-2008; FGDC-STD-014.7-2008; FGDC-STD-014.7b- } \\
\text { 2008; FGDC-STD-014.7c-2008; FGDC-STD-014.7d-2008; } \\
\text { FGDC-STD-014.7e-2008 } \\
\text { Organization: Federal Geographic Data Committee (FGDC) } \\
\text { Classification: Domain-specific integration interface }\end{array}$ \\
\hline GeoTIFF & $\begin{array}{l}\text { Description: GeoTIFF is a metadata format, which provides } \\
\text { geographic information to associate with the image data. } \\
\text { GeoTIFF implements the geographic metadata formally, using } \\
\text { compliant Tagged Image File (TIFF 6.0) tags and structures. } \\
\text { "GeoTIFF" refers to TIFF files, which have geographic (or } \\
\text { cartographic) data embedded as tags within the TIFF file. The } \\
\text { geographic data can then be used to position the image in the } \\
\text { correct location and geometry on the screen of a geographic } \\
\text { information display [GEOTIFF 2011]. } \\
\text { Standard Type: GeoTIFF/Revision } 1.0 \\
\text { Organization: geotiff.osgeo.org } \\
\text { Classification: Document format }\end{array}$ \\
\hline
\end{tabular}




\begin{tabular}{|c|c|}
\hline $\begin{array}{l}\text { Governmental Unit and Other } \\
\text { Geographic Area Boundaries }\end{array}$ & $\begin{array}{l}\text { Description: A specification for establishing of content } \\
\text { requirements for the collection and interchange of Government } \\
\text { units and legal entity boundary data and for facilitating the } \\
\text { maintenance and use of that information [FGDC 2010]. } \\
\text { Standard Type: FGDC-STD-014.5-2008 } \\
\text { Organization: Federal Geographic Data Committee (FGDC) } \\
\text { Classification: Domain-specific Integration Interfaces }\end{array}$ \\
\hline GRIdded Binary (GRIB) & $\begin{array}{l}\text { Description: Format specifications for representing } \\
\text { meteorological, gridded-point data [WMO 2010a]. } \\
\text { Standard Type: FM 92-IX Ext. GRIB; FM 92-VIII EXT. GRIB } \\
\text { Organization: World Meteorological Organization (WMO) } \\
\text { Classification: Domain-specific Integration Interfaces }\end{array}$ \\
\hline $\begin{array}{l}\text { Homeland Security Mapping } \\
\text { Standard - Point Symbology for } \\
\text { Emergency Management }\end{array}$ & $\begin{array}{l}\text { Description: The primary purpose of this standard is to } \\
\text { establish a common set of symbols for use by mapmakers in } \\
\text { support of emergency managers and first responders. It will } \\
\text { allow users to rapidly interpret map data and to be able to } \\
\text { disseminate consistent, usable information. This American } \\
\text { National Standard is applicable to all organizations that create } \\
\text { maps or otherwise display features for the Emergency } \\
\text { Management or First Responder communities. It is limited at } \\
\text { this time to support portrayal of point features that relate to the } \\
\text { emergency management and hazard mapping disciplines [ANSI } \\
\text { 2011b]. } \\
\text { Standard Type: ANSI INCITS 415-2006 } \\
\text { Organization: American National Standards Institute (ANSI); } \\
\text { International Committee for Information Technology Standards } \\
\text { (INCITS) } \\
\text { Classification: Domain-specific integration interface }\end{array}$ \\
\hline $\begin{array}{l}\text { OpenGIS Implementation } \\
\text { Specification for Geographic } \\
\text { Information - Simple Feature Access }\end{array}$ & $\begin{array}{l}\text { Description: The OpenGIS Simple Features Interface Standard } \\
\text { (SFS) provides a well-defined and common way for applications } \\
\text { to store and access feature data in relational or object-relational } \\
\text { databases, so that the data can be used to support other } \\
\text { applications through a common feature model, data store, and } \\
\text { information access interface. OpenGIS Simple Features are } \\
\text { geospatial features described using vector data elements such as } \\
\text { points, lines, and polygons [OGC 2011c]. } \\
\text { Standard Type: OGC 06-103r4 Version 1.2.1, OGC 05-126 } \\
\text { Organization: Open Geospatial Consortium, Inc (OGC) } \\
\text { Classification: Domain-specific integration interface }\end{array}$ \\
\hline $\begin{array}{l}\text { Spatial Data Transfer Standard } \\
\text { (SDTS) }\end{array}$ & $\begin{array}{l}\text { Description: The Spatial Data Transfer Standard (SDTS) base } \\
\text { specification (Parts 1, } 2 \text { and } 3 \text { ) describes the underlying } \\
\text { conceptual model and the detailed specifications for the content, } \\
\text { structure, and format for exchange of spatial data. Additional } \\
\text { parts (4, 5, } 6 \text { and potentially others) are added as profiles, each } \\
\text { of which defines specific rules and formats for applying SDTS } \\
\text { for the exchange of particular types of data [FGDC 2011d] }\end{array}$ \\
\hline
\end{tabular}




\begin{tabular}{|l|l|}
\hline & $\begin{array}{l}\text { Standard Type: FGDC-STD-002.1; FGDC-STD-002.5; FGDC- } \\
\text { STD-002.6; FGDC-STD-002.7-2000 } \\
\text { Organization: Federal Geographic Data Committee (FGDC) } \\
\text { Classification: Domain-specific integration interface }\end{array}$ \\
\hline $\begin{array}{l}\text { Standard for a U.S. National Grid } \\
\text { (USNG) }\end{array}$ & $\begin{array}{l}\text { Description: A standard is used to define the U.S. National Grid } \\
\text { and supports Universal Transverse Mercator (UTM) } \\
\text { coordinates, Military Grid Reference System (MGRS) grids, and } \\
\text { the specific grid presentation requirements. It is used for } \\
\text { acquisition/production of printed map and acquisition of } \\
\text { location service appliances with printed map products [FGDC } \\
\text { 2011e] } \\
\text { Standard Type: FGDC-STD-011-2001 } \\
\text { Organization: Federal Geographic Data Committee (FGDC) } \\
\text { Classification: Domain-specific integration interface }\end{array}$ \\
\hline
\end{tabular}

\subsubsection{Selected Communication Standards}

\begin{tabular}{|l|l|}
\hline \multicolumn{1}{|c|}{ Standard Title } & \multicolumn{1}{|c|}{ Overview } \\
\hline Common Alerting Protocol (CAP) & $\begin{array}{l}\text { Description: The Common Alerting Protocol (CAP) is a simple, } \\
\text { flexible data interchange format for collecting and distributing } \\
\text { "all-hazard” safety notifications and emergency warnings over } \\
\text { information networks and public alerting systems. In Web- } \\
\text { services applications, CAP provides a lightweight standard for } \\
\text { exchanging urgent notifications. CAP can also be used in data- } \\
\text { broadcast applications and over legacy data networks. CAP is } \\
\text { fully compatible with the existing national broadcast Emergency } \\
\text { Alert System (EAS) [OASIS 2011a]. It is an XML-related data } \\
\text { interchange standard for alerting and event notification } \\
\text { applications. The standard supports two functions: a standalone } \\
\text { protocol and a payload for Emergency Data Exchange Language } \\
\text { (EDXL) messages. } \\
\text { Standard Type: CAP-V1.1 } \\
\text { Organization: Organization for the Advancement of Structured } \\
\text { Information Standards (OASIS) } \\
\text { Classification: Domain-specific integration interface }\end{array}$ \\
\hline $\begin{array}{l}\text { Common Incident Management } \\
\text { Message Sets for Use by Emergency } \\
\text { Management Centers }\end{array}$ & $\begin{array}{l}\text { Description: This standard is the Base Standard for a family of } \\
\text { related standards that address the intercommunication needs of } \\
\text { emergency management centers and other types of centers } \\
\text { engaged in transportation incident management [IEEE 2010]. } \\
\text { Standard Type: IEEE 1512-2000, IEEE 1512.1, IEEE 1512.2, } \\
\text { IEEE 1512.3 } \\
\text { Organization: Institute of Electrical and Electronics Engineers } \\
\text { (IEEE) } \\
\text { Classification: Document Format }\end{array}$ \\
\hline
\end{tabular}




\begin{tabular}{|l|l|}
\hline Emergency Data Exchange & Description: Several organizations are collaborating on the \\
design and development of a suite of specifications under the \\
name “Emergency Data Exchange Language (EDXL)" [OASIS \\
2011b]. EDXL is an integrated framework for a wide range of \\
emergency data exchange standards to support operations, \\
logistics, planning, and finance. \\
Standard Type: EXDL Distribution Element, V. 1.0 (EDXL- \\
DE-V1.0); EDXL Resource Message Specification 1.0 Working \\
Draft Version 26 (EDXL-RM 1.0 v0026); EDXL Hospital \\
Availability Exchange v1.0 Public Review Draft 02 (EDXL- \\
HAVE-1.0-spec-pr02) \\
Organization: Organization for the Advancement of Structured \\
Information Standards (OASIS); Department of Homeland \\
Security (DHS); Emergency Interoperability Consortium (EIC) \\
Classification: Domain-specific integration interface
\end{tabular}

\subsubsection{Training System Standards}

\begin{tabular}{|l|l|}
\hline \multicolumn{1}{|c|}{ Standard Title } & \multicolumn{1}{|c|}{ Overview } \\
\hline $\begin{array}{l}\text { Sharable Content Object Reference } \\
\text { Model (SCORM) }\end{array}$ & $\begin{array}{l}\text { Description: SCORM is an XML-based framework used to } \\
\text { define and access information about learning objects so they can } \\
\text { be easily shared among different learning management systems } \\
\text { (LMSs). SCORM was developed in response to a United States } \\
\text { Department of Defense (DoD) initiative to promote } \\
\text { standardization in e-learning [ASTD 2011]. SCORM integrates } \\
\text { a set of related technical standards, specifications, and } \\
\text { guidelines designed to meet SCORM's high-level } \\
\text { requirements-accessible, interoperable, durable, and reusable } \\
\text { content and systems. SCORM content can be delivered to your } \\
\text { learners via any SCORM-compliant LSM using the same } \\
\text { version of SCORM [ADL 2011]. } \\
\text { Standard Type: SCORM 1.1, SCORM 1.2, SCORM 1.3 } \\
\text { Organization: U. S. Department of Defense (DoD) } \\
\text { Classification: Document format }\end{array}$ \\
\hline
\end{tabular}




\subsection{Data Sources}

This section identifies databases and other sources of data that may be used to develop or run incident management models, simulations, and training applications. The name of data source, a brief description of its contents, its access location, responsible organization, data formats used, as well a classification of the type of data is given below.

\begin{tabular}{|c|c|}
\hline Data Source Title & Overview \\
\hline Active Fire Mapping Program & $\begin{array}{l}\text { Description: The MODIS (Moderate Resolution Imaging } \\
\text { Spectroradiometer) Active Fire Mapping Program provides a near } \\
\text { real-time geospatial overview of the current wildland fire } \\
\text { situation at regional and national scales. Locations of current fires } \\
\text { and the extent of previous fire activity are ascertained using } \\
\text { satellite imagery acquired by the MODIS sensor. These fire data } \\
\text { are integrated with various sources of contextual spatial data and } \\
\text { information in a suite of geospatial data and mapping products. } \\
\text { This information is utilized by fire managers to assess the current } \\
\text { fire situation and serves as a decision support tool in strategic } \\
\text { decisions regarding fire suppression resource allocation. The data } \\
\text { and products provided by the program are also valuable for } \\
\text { numerous other fire-related applications. MODIS fire detection } \\
\text { data and products are continuously updated and published year } \\
\text { round to provide temporal and spatial coverage for the variable } \\
\text { fire conditions that occur year round on the North American } \\
\text { continent. The MODIS Active Fire Mapping Program provides } \\
\text { active fire detection and monitoring for the continental United } \\
\text { States, Alaska, Hawaii, and Canada [USDA 2010]. } \\
\text { Data Source: NASA Earth Observing System (EOS) Data } \\
\text { Gateway (EDG) } \\
\text { Organization: USDA Forest Service (USFS) Remote Sensing } \\
\text { Applications Center, NASA, the University of Maryland, the } \\
\text { National Interagency Fire Center } \\
\text { Format: KML/KMZ } \\
\text { Classification: Incidents, Environment }\end{array}$ \\
\hline $\begin{array}{l}\text { California Integrated Seismic } \\
\text { Network (CISN) Display }\end{array}$ & $\begin{array}{l}\text { Description: The California Integrated Seismic Network (CISN) } \\
\text { is a partnership among federal, state, and university agencies } \\
\text { involved in California earthquake monitoring. CISN Display is } \\
\text { part of a Web-enabled earthquake notification system alerting } \\
\text { users in near real-time of seismicity, and also valuable } \\
\text { geophysical information following a large earthquake. CISN } \\
\text { Display is a software package that rapidly receives earthquake } \\
\text { information via the Internet distributed by seismic networks } \\
\text { operating in the United States. It is a means of delivering } \\
\text { graphical earthquake information to users at emergency } \\
\text { operations centers, and other organizations. The CISN Display is } \\
\text { the front-end of a client/server architecture known as the } \\
\text { QuakeWatch system. It is comprised of the CISN Display (and } \\
\text { other potential clients), message queues, server, server "feeder" } \\
\text { modules, and messaging middleware, schema, and generators. }\end{array}$ \\
\hline
\end{tabular}




\begin{tabular}{|c|c|}
\hline & $\begin{array}{l}\text { Central to the CISN Display's role as a gateway to other } \\
\text { earthquake products is its comprehensive XML-schema. } \\
\text { Earthquake products deliverable to the CISN Display are } \\
\text { ShakeMap, Ground Displacement, Focal Mechanisms, Rapid } \\
\text { Notifications, OES Reports, and Earthquake Commentaries } \\
\text { [CISN 2010]. } \\
\text { Data Source: CISN Display Version } 1.31 \\
\text { Organization: California Integrated Seismic Network } \\
\text { Format: ShakeMap, CISN Display map } \\
\text { Classification: Domain-specific Integration Interface }\end{array}$ \\
\hline $\begin{array}{l}\text { Centers for Disease Control and } \\
\text { Prevention (CDC) Widgets }\end{array}$ & $\begin{array}{l}\text { Description: CDC.gov provides content in several useful ways, } \\
\text { via CDC e-mail updates, podcasts and RSS feeds. CDC widgets } \\
\text { are online CDC.gov applications, built by one Web site that can } \\
\text { be displayed onto another Web site. Available widgets include } \\
\text { Adult BMI Calculator, H1N1 (Swine Flu), Fraudulent H1N1 } \\
\text { Products, H1N1 School Guidance, Pet Health and Safety, Public } \\
\text { Health Image Library Image of the Day, Five Minutes or Less for } \\
\text { Health, Smoking and Tobacco Use, Flu IQ, Seasonal Flu } \\
\text { Updates, National Environmental Public Health Tracking } \\
\text { Program, and CDC Text Messages. [CDC 2010c]. } \\
\text { Data Source: CDC.gov } \\
\text { Organization: Centers for Disease Control and Prevention } \\
\text { Format: html, RSS } \\
\text { Classification: Incidents, Demographic and Behavior, } \\
\text { Environment, Controlling Document }\end{array}$ \\
\hline $\begin{array}{l}\text { Data Sets Available in the } \\
\text { DataFerrett System }\end{array}$ & $\begin{array}{l}\text { Description: DataFerrett is a unique data analysis and extraction } \\
\text { tool-with recoding capabilities—-to customize federal, state, and } \\
\text { local data to suit the user's requirements. TheDataWeb is the } \\
\text { infrastructure for intelligent browsing and accessing data across } \\
\text { the Internet. TheDataWeb provides access across the Internet } \\
\text { using the DataFerrett interface to use demographic, economic, } \\
\text { environmental, health, and other databases housed in different } \\
\text { systems in different agencies and organizations (Ferrett stands for } \\
\text { Federated Electronic Research, Review, Extraction, and } \\
\text { Tabulation Tool.) Some of the searchable data sets topics in the } \\
\text { DataFerrett application are American Community Survey (ACS), } \\
\text { Behavioral Risk Factor Surveillance System (BRFSS), National } \\
\text { Ambulatory Medical Care Survey (NAMCS), and Census } 2000 \\
\text { [CENSUS 2010]. } \\
\text { Data Source: DataFerrett system } \\
\text { Organization: U.S. Census Bureau } \\
\text { Format: XML/CAP 1.1, ATOM, RSS } \\
\text { Classification: Controlling Documents, Demographic and } \\
\text { Behavior, Resources }\end{array}$ \\
\hline $\begin{array}{l}\text { Disaster Management - Open } \\
\text { Platform for Emergency Networks } \\
\text { (DM-OPEN) }\end{array}$ & $\begin{array}{l}\text { Description: Disaster Management - Open Platform for } \\
\text { Emergency Networks (DM-OPEN) was created to establish } \\
\text { information exchange and collaboration between existing }\end{array}$ \\
\hline
\end{tabular}




\begin{tabular}{|c|c|}
\hline & $\begin{array}{l}\text { emergency preparedness information systems. DM-OPEN is a } \\
\text { non-proprietary operational interoperability backbone that } \\
\text { provides a set of non-proprietary "level playing field" web } \\
\text { services designed to enable disparate third-party applications, } \\
\text { systems, networks and devices to share information using open } \\
\text { interoperability standards. As a Federal infrastructure, DM- } \\
\text { OPEN is designed to support the delivery of real-time data and } \\
\text { situational awareness to public emergency responders in the field, } \\
\text { at operation centers and across all levels of response } \\
\text { management.The DM-OPEN mission is to enable a national } \\
\text { network of systems that facilitates data sharing between software } \\
\text { products serving the responder community. DM-OPEN also } \\
\text { serves as a test bed to facilitate the development of open, non- } \\
\text { proprietary consensus standards that support interoperable } \\
\text { information sharing for the emergency responder community } \\
\text { [FEMA 2010e]. } \\
\text { Data Source: DM-OPEN 2.0 } \\
\text { Organization: Department of Homeland Security (DHS) Federal } \\
\text { Emergency Management Agency (FEMA) } \\
\text { Format: WSDL, Map, CAP, EDXL-DE, HTTPS Servlet, SOAP } \\
\text { Classification: Incidents, Simulation Support, Controlling } \\
\text { Documents, Resources, Demographic and Behavioral }\end{array}$ \\
\hline FedStats & $\begin{array}{l}\text { Description: FedStats provides access to the full range of official } \\
\text { statistical information produced by the Federal Government } \\
\text { without having to know in advance which Federal agency } \\
\text { produces which particular statistic. With convenient searching } \\
\text { and linking capabilities to more than } 100 \text { agencies that provide } \\
\text { data and trend information on such topics as economic and } \\
\text { population trends, crime, education, health care, aviation safety, } \\
\text { energy use, and farm production [FEDSTATS 2010]. } \\
\text { Data Source: www.fedstats.gov } \\
\text { Organization: The Federal Interagency Council on Statistical } \\
\text { Policy } \\
\text { Format: HTML, spreadsheets } \\
\text { Classification: Resources, Demographic and Behavioral, } \\
\text { Environment, Controlling Documents }\end{array}$ \\
\hline $\begin{array}{l}\text { Geospatial Multi-Agency } \\
\text { Coordination Group (GeoMAC) }\end{array}$ & $\begin{array}{l}\text { Description: The Geospatial Multi-Agency Coordination Group } \\
\text { (GeoMAC) is an internet-based mapping application originally } \\
\text { designed for fire managers to access online maps of current fire } \\
\text { locations and perimeters in the conterminous } 48 \text { States and } \\
\text { Alaska. Using a standard web browser, fire personnel can view } \\
\text { this information to pinpoint the affected areas. With the growing } \\
\text { concern of western wildland fires in the summer of 2000, this } \\
\text { application has also become available to the public. In order to } \\
\text { give fire managers near real-time information, fire perimeter data } \\
\text { is updated daily based upon input from incident intelligence } \\
\text { sources, GPS data, infrared (IR) imagery from fixed wing and } \\
\text { satellite platforms. The GeoMAC web site allows users in remote }\end{array}$ \\
\hline
\end{tabular}




\begin{tabular}{|c|c|}
\hline & $\begin{array}{l}\text { locations to manipulate map information displays, zoom in and } \\
\text { out to display fire information at various scales and detail, and } \\
\text { print hard copy maps for use in fire information and media } \\
\text { briefings, dispatch offices and coordination centers. The fire } \\
\text { maps also have relational databases in which the user can display } \\
\text { information on individual fires such as name of the fire, current } \\
\text { acreage and other fire status information [GEOMAC 2010]. } \\
\text { Data Source: The GeoMAC web site } \\
\text { Organization: U.S. Department of the Interior, U.S. Department } \\
\text { of Agriculture, National Interagency Fire Center, U.S. Geological } \\
\text { Survey } \\
\text { Format: Map, Data } \\
\text { Classification: Incident, Spatial, Environment }\end{array}$ \\
\hline GIS Data Depot & $\begin{array}{l}\text { Description: The GeoCommunity GISDataDepot is an online } \\
\text { resource for GIS and Deospatial data. It provides GIS data from } \\
\text { multiple sources. Data provided by the GISDataDepot include } \\
\text { standard U.S. Geological Survey (USGS) digital raster graphic } \\
\text { (DRG) data, USGS Digital Elevation Model (DEM) data, USGA } \\
\text { orthoimagery data, and FEMA Flood Data. A DRG is a scanned } \\
\text { image of a USGS standard series topographic map, including all } \\
\text { map collar information. The USGS DEM data files are digital } \\
\text { representations of cartographic information in a raster form. } \\
\text { DEMs consist of a sampled array of elevations for a number of } \\
\text { ground positions at regularly spaced intervals. The } \\
\text { GeoCommunity has one of the largest online collections of } \\
\text { orthoimagery available in the world [GEOCOMM 2010]. } \\
\text { Data Source: GIS Data Depot } \\
\text { Organization: MindSites Group, Niceville, FL } \\
\text { Format: DEM, NWI, DLG, LU/LC, TIGER, E00, MIF } \\
\text { Classification: Environment }\end{array}$ \\
\hline Global Terrorism Database (GTD) & $\begin{array}{l}\text { Description: The Global Terrorism Database (GTD) is an open- } \\
\text { source database including information on terrorist events around } \\
\text { the world from } 1970 \text { through } 2008 \text { (with additional annual } \\
\text { updates planned for the future). Unlike many other event } \\
\text { databases, the GTD includes systematic data on domestic as well } \\
\text { as transnational and international terrorist incidents that have } \\
\text { occurred during this time period and now includes more than } \\
87,000 \text { cases. For each GTD incident, information is available on } \\
\text { the date and location of the incident, the weapons used and nature } \\
\text { of the target, the number of casualties, and--when identifiable-- } \\
\text { the group or individual responsible. The National Consortium for } \\
\text { the Study of Terrorism and Responses to Terrorism (START) } \\
\text { makes the GTD available via this online interface in an effort to } \\
\text { increase understanding of terrorist violence so that it can be more } \\
\text { readily studied and defeated [START 2010]. } \\
\text { Data Source: GTD } \\
\text { Organization: U.S. Department of Homeland Security/National }\end{array}$ \\
\hline
\end{tabular}




\begin{tabular}{|c|c|}
\hline & $\begin{array}{l}\text { Consortium for the Study of Terrorism and Responses to } \\
\text { Terrorism (START) } \\
\text { Format: Chart, Table, CSV } \\
\text { Classification: Incidents, Controlling Documents }\end{array}$ \\
\hline Incident Information System & $\begin{array}{l}\text { Description: The Incident Information System, InciWeb, is an } \\
\text { interagency all-risk incident information management system. } \\
\text { The system was developed with two primary missions: provide } \\
\text { the public a single source of incident related information, and } \\
\text { provide a standardized reporting tool for the Public Affairs } \\
\text { community. A number of supporting systems automate the } \\
\text { delivery of incident information to remote sources. This ensures } \\
\text { that the information regarding active incidents is consistent, and } \\
\text { the delivery is timely. Information posted on the website is for } \\
\text { information purposes only [INCIWEB 2010]. } \\
\text { Data Source: InciWeb } \\
\text { Organization: Inciweb.org } \\
\text { Format: Table, JPG } \\
\text { Classification: Incidents }\end{array}$ \\
\hline $\begin{array}{l}\text { National Fire Department Census } \\
\text { Database }\end{array}$ & $\begin{array}{l}\text { Description: The National Fire Department Census Database } \\
\text { provides an online address listing of U.S. fire departments } \\
\text { registered with U.S. Fire Administration (USFA) as well as some } \\
\text { basic information about each fire department. The purpose of the } \\
\text { census, which is ongoing, is to create a national database for use } \\
\text { by USFA to conduct special studies that will guide program } \\
\text { decision-making and to improve direct communication with } \\
\text { individual fire departments [USFA 2010a]. } \\
\text { Data Source: USFA's National Fire Department Census } \\
\text { Database } \\
\text { Organization: U.S. Fire Administration (USFA) } \\
\text { Format: Report/Online Table } \\
\text { Classification: Resources }\end{array}$ \\
\hline $\begin{array}{l}\text { National Fire Incident Reporting } \\
\text { System (NFIRS) }\end{array}$ & $\begin{array}{l}\text { Description: The National Fire Incident Reporting System } \\
\text { (NFIRS) has two objectives: to help State and local governments } \\
\text { develop fire reporting and analysis capability for their own use, } \\
\text { and to obtain data that can be used to more accurately assess and } \\
\text { subsequently combat the fire problem at a national level. To meet } \\
\text { these objectives, the USFA has developed a standard NFIRS } \\
\text { package that includes incident and casualty forms, a coding } \\
\text { structure for data processing purposes, manuals, computer } \\
\text { software and procedures, documentation and a National Fire } \\
\text { Academy training course for utilizing the system [USFA 2010b]. } \\
\text { Data Source: USFA NFIRS 5.0 Client Software Version 5.7.0 } \\
\text { Organization: U.S. Fire Administration (USFA) } \\
\text { Format: NFPA 901 } \\
\text { Classification: Incidents, Controlling Documents }\end{array}$ \\
\hline
\end{tabular}




\begin{tabular}{|c|c|}
\hline $\begin{array}{l}\text { National Incident Management } \\
\text { System - Incident Resource } \\
\text { Inventory System (NIMS-IRIS) }\end{array}$ & $\begin{array}{l}\text { Description: National Incident Management System - Incident } \\
\text { Resource Inventory System (NIMS-IRIS) is a database } \\
\text { management tool that allows emergency responders to enter } \\
\text { typed resources and select specific resources for mutual aid } \\
\text { purposes based upon mission requirements, capability of } \\
\text { resources, and response time. NIMS-IRIS tracks equipment, } \\
\text { communications, contracts, facilities, responders, services, } \\
\text { supplies, and teams [FEMA 2010f]. } \\
\text { Data Source: NIMS-IRIS Version } 2.2 \\
\text { Organization: Federal Emergency Management Agency } \\
\text { (FEMA) } \\
\text { Format: EDXL } \\
\text { Classification: Resources }\end{array}$ \\
\hline $\begin{array}{l}\text { National Response Center (NRC) } \\
\text { Data Query Page }\end{array}$ & $\begin{array}{l}\text { Description: The National Response Center (NRC), the federal } \\
\text { government's national communications center, is staffed } 24 \text { hours } \\
\text { a day by U.S. Coast Guard officers and marine science } \\
\text { technicians and serves as the sole federal point of contact for } \\
\text { reporting all hazardous substances and oil spills. The NRC } \\
\text { maintains reports of all releases and spills in a national database. } \\
\text { The NRC has made available yearly data files for download and } \\
\text { offline management. Each file represents a particular calendar } \\
\text { year and contains data related to incidents, which occurred during } \\
\text { that year. NRC report categories include aircraft report, } \\
\text { continuous release report, fixed report, mobile report, pipeline } \\
\text { report, platform report, railroad report, sheen report, storage tank } \\
\text { report, and vessel report [NRC 2010]. } \\
\text { Data Source: NRC DOWNLOAD DATA } \\
\text { Organization: National Response Center } \\
\text { Format: XLS, HTML } \\
\text { Classification: Incidents, Environment, Controlling Documents }\end{array}$ \\
\hline National Situation Updates & $\begin{array}{l}\text { Description: National Situation Updates are compiled for use in } \\
\text { emergency management planning and operational activities. } \\
\text { Updates include information and graphics gathered from a variety } \\
\text { of sources including other federal agencies and departments, state } \\
\text { and local government, and the news media. Updates are } \\
\text { published daily, Monday through Friday, by the Information } \\
\text { Coordination Unit, Response and Recovery Directorate at FEMA } \\
\text { Headquarters [FEMA 2010g]. } \\
\text { Data Source: FEMA Emergency Managers } \\
\text { Organization: Federal Emergency Management Agency } \\
\text { (FEMA) } \\
\text { Format: Report } \\
\text { Classification: Incidents, Controlling Documents }\end{array}$ \\
\hline $\begin{array}{l}\text { RAND Database of Worldwide } \\
\text { Terrorism Incidents (RDWTI) }\end{array}$ & $\begin{array}{l}\text { Description: The RAND Corporation has developed and } \\
\text { maintained a database of terrorism incidents stretching back to } \\
\text { 1972, which contains comprehensive information on international } \\
\text { and domestic terrorism. Over the years, many public and private } \\
\text { sponsors have contributed to the maintenance of the RAND }\end{array}$ \\
\hline
\end{tabular}




\begin{tabular}{|c|c|}
\hline & $\begin{array}{l}\text { Database of Worldwide Terrorism Incidents (RDWTI). The new } \\
\text { subscription-based RDWTI, launched in January 2009, is a fully } \\
\text { searchable and interactive database [RAND 2010a]. } \\
\text { Data Source: RDWTI } \\
\text { Organization: RAND Corporation, Department of Health and } \\
\text { Human Services (HHS) } \\
\text { Format: txt, pie charts, and chronological graphs } \\
\text { Classification: Incidents }\end{array}$ \\
\hline $\begin{array}{l}\text { Rand Public Health Preparedness } \\
\text { Exercise Database }\end{array}$ & $\begin{array}{l}\text { Description: The Rand Corporation RAND assessed existing } \\
\text { public health preparedness exercises and developed a database of } \\
\text { those exercises that met the quality criteria for use by state and } \\
\text { local public health departments. It is primarily intended for state } \\
\text { and local public health officials. The database provides a list of } \\
\text { possible exercises performed along with criteria rating the } \\
\text { success of each exercise. There are fourteen design criteria used } \\
\text { to rate each exercise. These criteria are: 1) clearly stated goals; } \\
\text { 2) clearly stated objectives; 3) the objectives are appropriate } \\
\text { given the goals; 4) each objective is addressed during the } \\
\text { exercise; 5) objectives are measurable; } 6 \text { ) the scenario is } \\
\text { appropriate given the goals and objectives; 7) the scenario is } \\
\text { internally consistent; 8) scenario is "a realistic depiction of the } \\
\text { capabilities and resources likely to be available to a participating } \\
\text { health jurisdiction;” 9) clear guidance about participants; 10) all } \\
\text { participants are engaged; } 11 \text { ) exercise can be replicated; 12) } \\
\text { results in action items; 13) feedback is solicited from participants; } \\
\text { 14) can be completed within the given timeframe. The goal of } \\
\text { this database is “to identify the best exercises to help local and } \\
\text { state public health departments prepare for public health } \\
\text { emergencies” [RAND 2010b]. } \\
\text { Data Source: Rand Public Health Preparedness Exercise } \\
\text { Database } \\
\text { Organization: RAND Corporation, Department of Health and } \\
\text { Human Services (HHS) } \\
\text { Format: XLS, Pie charts, Chronological graphs } \\
\text { Classification: Training, Resources }\end{array}$ \\
\hline Responder Knowledge Base (RKB) & $\begin{array}{l}\text { Description: The Responder Knowledge Base (RKB) is a } \\
\text { decision support infrastructure for the responder community that } \\
\text { provides information on commercial equipment and technology } \\
\text { to the state, local, and tribal homeland security community to } \\
\text { assist them with their purchasing and operational equipment } \\
\text { decisions. RKB provides emergency responders, purchasers, and } \\
\text { planners with a trusted, integrated, online source of information } \\
\text { on products, standards, certifications, grants, and other } \\
\text { equipment-related information. The RKB hosts the online } \\
\text { interactive version of the FEMA Authorized Equipment List } \\
\text { (AEL), which is provided in an interactive format and linked to } \\
\text { relevant information such as applicable standards. The RKB also } \\
\text { provides the official online version of the InterAgency Board's } \\
\text { Standardized Equipment List (SEL). The RKB is the only site in }\end{array}$ \\
\hline
\end{tabular}




\begin{tabular}{|c|c|}
\hline & $\begin{array}{l}\text { existence that provides an integrated display of the AEL and } \\
\text { SEL. The AEL is the generic list of equipment items allowable } \\
\text { under several Department of Homeland Security (DHS) grant } \\
\text { programs, including the Homeland Security Grant Program. This } \\
\text { choice displays only the official AEL items. The SEL includes } \\
\text { recommended features and operating considerations. This choice } \\
\text { displays only the SEL. The RKB site has added special features } \\
\text { such as Mission Critical Hints, the ability to display side by side } \\
\text { comparisons of products, and an Ask an Expert feature [RKB } \\
\text { 2010]. } \\
\text { Data Source: RKB Version } 3.9 \\
\text { Organization: Federal Emergency Management Agency } \\
\text { Format: Report/Online table } \\
\text { Classification: Incidents, Resources, Controlling Documents, } \\
\text { Investigative Intelligence, Demographic and Behavioral, } \\
\text { Environment, Training }\end{array}$ \\
\hline $\begin{array}{l}\text { Storm Prediction Center (SPC) } \\
\text { Forecast Products }\end{array}$ & $\begin{array}{l}\text { Description: The Storm Prediction Center (SPC) of the National } \\
\text { Weather Service (NWS) is providing tornado/severe } \\
\text { thunderstorm watches, mesoscale discussions, convective day 1-3 } \\
\text { outlooks, fire weather outlooks, and watch, warning and advisory } \\
\text { display through Really Simple Syndication (RSS) [NOAA 2010]. } \\
\text { Data Source: SPC Products RSS Feeds } \\
\text { Organization: National Oceanic and Atmospheric } \\
\text { Administration (NOAA) } \\
\text { Format: RSS, XML } \\
\text { Classification: Incidents, Demographic and Behavior, } \\
\text { Environment }\end{array}$ \\
\hline $\begin{array}{l}\text { Texas Natural Resources } \\
\text { Information System (TNRIS) }\end{array}$ & $\begin{array}{l}\text { Description: TNRIS was established by the Legislature in } 1968 \\
\text { as the Texas Water-Oriented Data Bank. In 1972, after four years } \\
\text { of growth and diversification, it was renamed the Texas Natural } \\
\text { Resources Information System. The mission of TNRIS is to } \\
\text { provide a "centralized information system incorporating all Texas } \\
\text { natural resource data, socioeconomic data related to natural } \\
\text { resources, and indexes related to that data that are collected by } \\
\text { state agencies or other entities." TNRIS's data storehouse } \\
\text { comprises the most comprehensive set of geographic data for the } \\
\text { State of Texas. It contains over 1,000,000 frames of Aerial } \\
\text { Photography and over } 50 \text { unique datasets that add up to over } 500 \\
\text { gigabytes of data. Access digital datasets directly through the } \\
\text { online Data Search \& Download, or go to Ordering Services to } \\
\text { work with TNRIS staff on a custom order [TNRIS 2010]. } \\
\text { Data Source: TNRIS Data Catalog } \\
\text { Organization: Texas Water Development Board } \\
\text { Format: USGS DEM, Mr SID } \\
\text { Classification: Resources }\end{array}$ \\
\hline $\begin{array}{l}\text { Unified Incident Command and } \\
\text { Decision Support (UICDS) }\end{array}$ & $\begin{array}{l}\text { Description: UICDS is the "middleware foundation" that enables } \\
\text { information sharing and decision support among commercial, }\end{array}$ \\
\hline
\end{tabular}




\begin{tabular}{|c|c|}
\hline & $\begin{array}{l}\text { government, and academic incident management technologies } \\
\text { used to support the National Response Framework (NRF) and the } \\
\text { National Incident Management System (NIMS), including the } \\
\text { Incident Command System (ICS), in order to prevent, protect, } \\
\text { respond, and recover from natural, technological, and terrorist } \\
\text { events. UICDS links homeland security and emergency } \\
\text { management organizations, from incident command at the scene } \\
\text { of an emergency to local and state operations centers to federal } \\
\text { departments and agencies, from intelligence fusion centers to } \\
\text { transportation management centers to health service } \\
\text { organizations, and many other groups [UICDS 2010]. } \\
\text { Data Source: UICDS Technology Provider } \\
\text { Organization: Science Applications International Corporation } \\
\text { (SAIC) } \\
\text { Format: NIEM-based data exchange, Multiple data } \\
\text { communication standards } \\
\text { Classification: Incidents }\end{array}$ \\
\hline $\begin{array}{l}\text { Wireless Information System for } \\
\text { Emergency Responders (WISER) }\end{array}$ & $\begin{array}{l}\text { Description: WISER is a system designed to assist first } \\
\text { responders in hazardous material incidents. WISER provides a } \\
\text { wide range of information on hazardous substances, including } \\
\text { substance identification support, physical characteristics, human } \\
\text { health information, and containment and suppression advice. } \\
\text { WISER is available for download as a standalone application on } \\
\text { Windows Mobile devices, Palm OS PDAs, Apple iPhone and } \\
\text { iPod Touch, BlackBerry devices, Microsoft Windows PCs, and } \\
\text { via WebWISER [WISER 2010]. } \\
\text { Data Source: WISER Version 4.3, WebWISER, WISER for } \\
\text { BlackBerry Version 1.0, WISER for iPhone/iPOD Touch Version } \\
1.0 \\
\text { Organization: The National Library of Medicine (NLM) } \\
\text { Format: Report } \\
\text { Classification: Incidents, Controlling Documents, Demographic } \\
\text { and Behavior, Environment }\end{array}$ \\
\hline
\end{tabular}

\section{Discussions and Recommendations}

This section is intended to capture practices and issues relevant to program sponsors, project managers, researchers, developers, and implementers of M\&S of incident management for homeland security applications. The resources presented in section 6 and research, development and implementation experiences are used to identify the best practices to be followed for future efforts and to provide uncertainties, cautions and warnings for use of such applications. Further, the resources in section 6 are compared with the information in sections 4 and 5 to identify the unmet needs and requirements. These unmet needs and requirements are used to identify and prioritize the research, development, standards, and implementation issues that should be addressed going forward. This section hence provides a summary of discussion topics and recommendations that are divided into three major areas:

- Identification of best practices (Section 7.1) 
- Uncertainties, cautions and warnings regarding expectations of these models and simulations (Section 7.2)

- Research, development, standards and implementation issues that may need to be addressed by the research community, program sponsors, and stakeholders to improve the quality and utility of incident management models and simulations (Section 7.3)

\section{1. $\quad$ Best Practices}

Best practices are really only effective if a methodology is well defined for a given problem solving approach. For example, the LUMAS model shows how learning influences a documented methodology, and the link between $\mathrm{L}$ and $\mathrm{M}$ in the LUMAS model is where best practice is encountered by the user of a methodology. Computer models and simulations are tools in a variety of problem solving methodologies such as operations research, systems engineering, and management science, where methodology is defined as a collection of related processes, methods, and tools. Methodologies evolve as they are used by practitioners to address new problems and as new technologies and tools are developed to support them. Methodological advances are encouraged by documenting existing methods, processes and tools and by updating these periodically based on lessons learned and best practice from practical experience. This section will identify recommended approaches and best practices for solving different types of incident management modeling problems.

A variety of M\&S approaches, methodologies, and tools are currently available. Some are more suitable to solving certain classes of problems than others. This section will identify recommended approaches and best practices for solving different types of incident management modeling problems.

- $\quad$ Provide tools that can be used at the local level for incident management or training purposes

- Use various test and validation methods

- Provide tools that do not require sophisticated and expensive system support

- Provide distributed web-based tools that allow local governments to develop and run custom exercises.

\subsection{Uncertainties, Cautions and Warnings}

This sub-section is intended to highlight and document the limitations associated with M\&S applications to minimize improper use and highlight potential areas for further development. Models provide results with varying levels of error and uncertainty. M\&S application requires significant effort and hence they should be utilized only when appropriate, i.e., they should be considered for complex problems that cannot be addressed using other analytical options. The level of detail and specificity achieved by using the most sophisticated models and simulations may not be practical or necessary for all assets, systems, or networks. In these circumstances, a simplified dependency and interdependency analysis based on expert judgment may provide sufficient insight to make informed risk management decisions in a timely manner [DHS 2009a].

For applications that are identified as suitable for M\&S applications, it should be recognized that models provide results with varying levels of error and uncertainty. Analysts should ensure that decision-makers understand the uncertainties in M\&S results and other limitations such as the ones listed below.

- $\quad$ Training exercises may not create the stress conditions and state of mind in the response personnel that would occur during a real incident such as a massive failure or attack.

- Incident command models are particularly susceptible to variations in predicted results due to difficulties in precisely modeling human behaviors and random occurrences in real incidents. 
- Incident management systems in various agencies and local governments often define similar organizations, operations, and responsibilities differently

- Incident data may be required in different formats for different agencies and local governments complicating the implementation of simulation-based exercises

- Data inconsistencies between simulated exercises and real incidents may affect the results and perceptions.

- Communication difficulties and incompatibilities between systems may not be accurately reflected in training exercises.

\subsection{Research, Development, Standards, and Implementation Issues}

A number of research, development, standards, and implementation issues remain to be addressed. An initial straw man list follows:

- Identification of appropriate models, simulations, tools, and databases to address incident management analysis needs

- Identification of common models, simulations, tools, and databases that can be shared by incident management organizations

- Development of systems dynamics models to identify critical issues and interactions for different incident management systems

- Identification of technical gaps and needs for models, simulations, tools, and databases

- Increasing reality in incident management M\&S training exercises and devices

- Access to and usage of incident management M\&S applications by system personnel

- Use of a system-of-systems engineering approach to the development of applications

- Development of system requirements specifications for incident management models, simulations, tools, and databases

- Use of UML/SysML in specification of incident management systems and M\&S applications

- Development of simulation application architectures to enable module integration and standard data interfaces to import data from external databases

- Use of object-oriented models in incident management M\&S

- Development of M\&S applications as open systems

- Integration of incident management models and simulations

- Establishment of security and protection mechanisms for sensitive data

- Return on investment to stakeholders and sponsors for research projects

- Ownership and usage of publicly vs. privately developed models, simulations, tools, and databases

\section{Conclusion}

This initial version of the document is the starting point of an effort to capture the current knowledge relevant to $\mathrm{M} \& \mathrm{~S}$ of incident management for homeland security applications. It identifies the needs, translates them into requirements and provides summary information on resources available to meet the needs and requirements. The information on needs, requirements, and resources is used together with research, development, and implementation experiences to distill practices and issues for future efforts.

This version will be used to facilitate input from domain experts in a workshop setting. It is hoped that the next version updated with such input will provide value as a reference for program managers, project managers, researchers, developers, and implementers of M\&S of incident management for homeland security applications. Use of the updated document as a common reference may help increase the 
awareness across the associated communities and help enhance collaborative efforts for homeland security applications of M\&S for incident management.

\section{References}

[ADL 2011]

[ANL 2010a]

[ANL 2010b]

[ANSI 2010]

[ANSI 2011a]

[ANSI 2011b]

[ANSI 2011c]

[ASTM 2010]

[ATSDR 2010]

[Balci 1998]

[Beck 2009]

[Belk 2006]

Advanced Distributed Learning Sharable Content Object Reference Model (SCORM). Available via:

http://www.adlnet.gov/Technologies/scorm/default.aspx [accessed Jan. 10, 2011].

LPAT: Logistics and Process Analysis Tool. Decision and Information Sciences Division. Argonne National Laboratory. Available via:

http://www.dis.anl.gov/projects/lpat.html [accessed Nov. 21, 2010]

RESTORE. Technology Development and Commercialization. Argonne National Laboratory. Available via:

http://www.anl.gov/techtransfer/Software_Shop/RESTORE/RESTORE.html [accessed Nov. 21, 2010]

ANSI INCITS 398-2008: Information Technology - Common Biometric Exchange Formats Framework (CBEFF). American National Standards Institute (ANSI). Available via:

http://webstore.ansi.org/RecordDetail.aspx?sku=ANSI+INCITS+398-2008 [accessed Nov. 17, 2010]

ANSI Standards Store - Spatial Data Standard for Facilities, Infrastructure, and Environment (SDSFIE). American National Standards Institute (ANSI).

Available via:

http://webstore.ansi.org/RecordDetail.aspx?sku=ANSI+INCITS+353-2006 [accessed Jan. 15, 2011].

ANSI Standards Store - Homeland Security Mapping Standard: Point Symbology for Emergency Management. American National Standards Institute (ANSI). Available via:

http://webstore.ansi.org/RecordDetail.aspx?sku=ANSI+INCITS+415-2006 [accessed Mar. 25, 2011].

ANSI Standards Store - Unified Modeling Language (UML). American National Standards Institute (ANSI). Available via:

http://webstore.ansi.org/RecordDetail.aspx?sku=ISO\%2fIEC+19501\%3a2005\&s ource=google\&adgroup=iso9\&keyword=iso\%2Fiec\%2019501 [accessed Jan. 28, 2011].

ASTM Standards. ASTM International. Available via: http://www.astm.org/ [accessed Nov. 17, 2010]

Toxic Substances Portal. Agency for Toxic Substances and Disease Registry (ATSDR). Available via: http://www.atsdr.cdc.gov/MHMI/index.asp\# / [accessed Nov. 17, 2010]

Verification, Validation, and Testing. In Handbook of Simulation: Principles, Methodology, Advances, Applications, and Practice. Edited by J. Banks. WileyInterscience.

Beck, T., J. Bergenthal, D. Macannuco, 2009. Federation of authoritative disaster models with incident management constructive simulation. In Proceedings of the IEEE Conference on Technologies for Homeland Security, 2009 (HST '09). May 11-12, Boston, MA. Pages 401-408.

Belk, D., M. Burger, J. Moran, M. Newbauer, and J. Roth, 2006. WPL:

Simulation Technology to Support Homeland Defense. In Proceedings of the 
[BostonDyn 2007]

[Breakaway 2010]

[CDC 2010a]

[CDC 2010b]

[CDC 2010c]

[CENSUS 2010]

[Chamberlain 2006]

[Checkland 2000]

[CISN 2010]

[CWID 2004]

[DEVS 2011]

[DHS 2003]

[DHS 2008a]

[DHS 2008b]
2006 Spring Simulation Interoperability Workshop, Paper No. 06S-SIW-081. Available on-line via Digital Library of the Simulation Interoperability Standards Organization: http://www.sisostds.org/DigitalLibrary.aspx [accessed May 2, 2011]

DI-Guy: Human Simulation Software. Boston Dynamics. Available via: http://www.diguy.com/diguy/ [accessed Nov. 21, 2010]

Incident Commander ${ }^{\mathrm{TM}}$ NIMS-compliant training tool for Homeland Security.

Breakaway Ltd. Available via: http://www.breakawaygames.com/seriousgames/solutions/homeland/ [accessed Nov. 21, 2010]

Interim Planning Guidance for Preparedness and Response to a Mass Casualty Event Resulting from Terrorist Use of Explosives. Centers for Disease Control and Prevention (CDC). Available via:

http://www.bt.cdc.gov/masscasualties/pdf/CDC_Guidance-508.pdf [accessed Nov. 17, 2010]

Emergency Preparedness and Response. Centers for Disease Control and Prevention (CDC). Available via:

http://www.bt.cdc.gov/masscasualties/preparingterroristbombing.asp [accessed Nov. 17, 2010]

CDC.gov Widgets and Gadgets. Centers for Disease Control and Prevention (CDC). Available via: http://www.cdc.gov/widgets/ [accessed Nov. 17, 2010]

TheDataWeb. U.S. Census Bureau. Available via:

http://dataferrett.census.gov/datasets.html [accessed Nov. 17, 2010]

Chamberlain, R., and T. Metivier, 2006. Joint Non-kinetic Effects Model

(JNEM) - A Six Month Success Story. In Proceedings of the 2006

Interservice/Industry Training, Simulation \& Education Conference (I/ITSEC).

Available via: http://ntsa.metapress.com/link.asp?id=elk893hvkevccjnn;

Presentation slides available via: http://trs-

new.jpl.nasa.gov/dspace/bitstream/2014/41283/1/06-3712.pdf [accessed July 21, 2010]

Checkland, Peter. SSM: A Thirty-Year Retrospective. Systems Research and Behavioral Science, November 2000.

The California Integrated Seismic Network (CISN). Advanced National Seismic System (ANSS). Available via: http://www.cisn.org/ [accessed Nov. 17, 2010] Area Security Operations Command and Control ASSOC. Joint Warrior Interoperability Demonstration 2004 Final Report. Coalition Warrior Interoperability Demonstration (CWID). Available via: http://www.cwid.js.mil/public/cwid05fr/htmlfiles/u209war.html [accessed Nov. 21, 2010]

Discrete-Event Modeling and Simulation (DEVS) Standardization Group. Available via: http://cell-devs.sce.carleton.ca/devsgroup/ [accessed Jan. 25, 2011].

HSPD-5 Homeland Security Presidential Directive \#5. Available via: http://www.dhs.gov/xnews/releases/press_release_0105.shtm [accessed November 15, 2010]

National Incident Management System. U.S. Department of Homeland Security. Available via: http://www.fema.gov/pdf/emergency/nims/NIMS_core.pdf [accessed April 3, 2011]

National Response Framework. U.S. Department of Homeland Security. Available via: http://www.fema.gov/pdf/emergency/nrf/nrf-core.pdf [accessed April 3, 2011] 
[DHS 2009a] National Infrastructure Protection Plan. U.S. Department of Homeland Security. Available via: http://www.dhs.gov/xlibrary/assets/NIPP_Plan.pdf [accessed Feb. 27, 2011]

[DHS 2009b] Infrastructure and Geophysical Projects. U.S. Department of Homeland Security. Available via:

http://www.dhs.gov/files/programs/gc_1218480826191.shtm\#content [accessed November 15, 2010]

[DHS 2010a]

[DHS 2010b]

DHS Lexicon: Terms and Definitions. Office of the Secretary, Executive Secretariat, U.S. Department of Homeland Security. January 2010 edition (with 9/14/2010 update).

National Emergency Communications Plan. U.S. Department of Homeland Security. Available via:

http://www.dhs.gov/xlibrary/assets/national_emergency_communications_plan.p df [accessed Nov. 17, 2010]

[DHS 2010c] National Strategy for Homeland Security. U.S. Department of Homeland Security. Available via:

http://www.dhs.gov/xlibrary/assets/nat_strat_homelandsecurity_2007.pdf [accessed Nov. 17, 2010]

[DHS 2010d] The Integrated Modeling, mapping, and Simulation (IMMS) Program. U.S. Department of Homeland Security. Available via: Integrated Modeling, Mapping, and Simulation. U.S. Department of Homeland Security. Available via: https://dhs-summit.us/files/201002_IMMS_program_overview.pdf [accessed Nov. 22, 2010]

[DoD 2006] VV\&A Recommended Practices Guide (RPG). U.S. Department of Defense Modeling and Simulation Coordination Office. RPG Build 3.0. September 2006. Available on-line via: http://vva.msco.mil/ [last accessed Oct. 1, 2010].

[DoD 2009] DoD Modeling and Simulation (M\&S) Verification, Validation, and Accreditation (VV\&A). Department of Defense Instruction Number 5000.61. December 9, 2009. Available on-line via:

http://www.dtic.mil/whs/directives/corres/pdf/500061p.pdf [last accessed October 4, 2010]

[DoD 2010] DoD Modeling and Simulation Glossary. U.S. Department of Defense. March 2010. Available via:

http://www.msco.mil/files/Draft_MS_Glossary_March_B_version.pdf [accessed April 20, 2011]

[DODCCRP 2004] Morse, K. 2004. Web Enabling HLA Compliant Simulations to Support Network Centric Applications. 2004 Command and Control Research and Technology Symposium. Available via: http://www.dodccrp.org/events/2004_CCRTS/CD/presentations/172.pdf [accessed Mar. 25, 2011]

[DOT 2010] Incident Command System. U.S. Department of Transportation. Available via: http://ops.fhwa.dot.gov/eto_tim_pse/about/ics.htm [accessed Nov. 17, 2010]

[ECIG 2010] EAS-CAP Industry Group Working Group Documents. EAS-CAP Industry Group. Available via: http://www.eas-cap.org/documents.htm [accessed Nov. 17, 2010]

[ECS 2010] Emergency Management Staff Trainer (EMST). Engineering \& Computer Simulations , Inc. Available via: http://www.ecsorl.com/solutions/products/webbased-simulations/emergency-management-staff-trainer-emst/ [accessed Nov. 21, 2010]

[EMAP 2010] The Emergency Management Accreditation Program (EMAP). Available via: http://www.emaponline.org/ [accessed Nov. 17, 2010] 
[ETC 2010a]

[ETC 2010b]

[FEDSTATS 2010]

[FEMA 2004]

[FEMA 2009]

[FEMA 2010]

[FEMA 2010a]

[FEMA 2010b]

[FEMA 2010c]

[FEMA 2010d]

[FEMA 2010e]

[FEMA 2010f]

[FEMA 2010g]

[FEMA 2010h]

[FGDC 2010]
Incident Command (ADMS-COMMAND). Environmental Tectonics Corporation. Available via:

http://www.admstraining.com/products_incident.php [accessed Nov. 21, 2010].

Emergency Operations Center (ADMS-EOC). Environmental Tectonics

Corporation. Available via: http://www.admstraining.com/products_eoc.php [accessed Nov. 21, 2010].

FedStats. FedStates.gov. Available via: http://www.fedstats.gov/ [accessed Nov. 17, 2010]

NIMS and the Incident Command System. Federal Emergency Management Agency (FEMA). Available via:

http://www.fema.gov/txt/nims/nims_ics_position_paper.txt [accessed November 15, 2010]

National Planning Scenarios. Federal Emergency Management Agency (FEMA). Available via:

http://www.fema.gov/pdf/media/factsheets/2009/npd_natl_plan_scenario.pdf [accessed November 15, 2010]

Incident Command System (ICS). Federal Emergency Management Agency (FEMA). Available via:

http://www.fema.gov/emergency/nims/IncidentCommandSystem.shtm [accessed November 15, 2010]

Developing and maintaining Emergency Operations Plans. Federal Emergency Management Agency (FEMA). Available via:

http://www.fema.gov/about/divisions/cpg.shtm [accessed Nov. 17, 2010]

National Incident Management System. 2008. Federal Emergency Management Agency (FEMA). Available via: http://www.fema.gov/pdf/emergency/nims/NIMS_core.pdf [accessed Nov. 17, 2010]

National Preparedness Guidelines. 2007. Federal Emergency Management Agency (FEMA). Available via: http://www.fema.gov/pdf/government/npg.pdf [accessed Nov. 17, 2010]

National Response Framework. 2008. Federal Emergency Management Agency (FEMA). Available via: http://www.fema.gov/pdf/emergency/nrf/nrf-core.pdf [accessed Nov. 17, 2010]

Open Web Services. Federal Emergency Management Agency (FEMA). Available via:

http://www.fema.gov/about/programs/disastermanagement/open/index.shtm [accessed Nov. 17, 2010]

Resource Management. Federal Emergency Management Agency (FEMA). Available via: http://www.fema.gov/emergency/nims/ResourceMngmnt.shtm [accessed Nov. 17, 2010]

Emergency Managers - National Situation Updates. Federal Emergency Management Agency (FEMA). Available via: http://www.fema.gov/emergency/reports/index.shtm [accessed Nov. 17, 2010] Exercise. Federal Emergency Management Agency (FEMA). Available via: http://www.fema.gov/prepared/exercise.shtm [accessed Nov. 22, 2010] Geographic Information Framework Data Standard. Federal Geographic Data Committee (FGDC). Available via:

http://www.fgdc.gov/standards/projects/FGDC-standards-projects/frameworkdata-

standard/GI_FrameworkDataStandard_Part5_GovernmentalUnitBoundaries.pdf [accessed January 31, 2011]. 
[FGDC 2011a]

[FGDC 2011b]

[FGDC 2011c]

[FGDC 2011d]

[FGDC 2011e]

[GEOAPI 2011]

[GEOCOMM 2010]

[GEOMAC 2010]

[GEOTIFF 2011]

[Holtermann 2010]

[Hydra 2010]

[IEEE 2010]

[IEEE 2011c]

[IHS2011a]

[INCIWEB 2010]

[INCOSE 2008]
Content Standard for Digital Geospatial Metadata. Federal Geographic Data Committee (FGDC). Available via:

http://www.fgdc.gov/standards/projects/FGDC-standards-

projects/metadata/base-metadata/?searchterm=FGDC-STD-001 [accessed Mar.

25, 2011].

Content Standard for Digital Geospatial Metadata: Extensions for Remote

Sensing Metadata. Federal Geographic Data Committee (FGDC). Available via: http://www.fgdc.gov/standards/projects/FGDC-standards-

projects/csdgm_rs_ex/MetadataRemoteSensingExtens.pdf/view?searchterm=FG DC-STD-012 [accessed Mar. 25, 2011].

Geographic Information Framework data Standard. Federal Geographic Data

Committee (FGDC). Available via:

http://www.fgdc.gov/standards/projects/FGDC-standards-projects/framework-

data-standard/framework-data-standard [accessed Mar. 25, 2011].

Spatial Data Transfer Standard (SDTS). Federal Geographic Data Committee (FGDC). Available via:

http://www.fgdc.gov/standards/projects/FGDC-standards-

projects/SDTS/?searchterm=sdts [accessed Mar. 25, 2011].

United States National Grid. Federal Geographic Data Committee (FGDC). Available via: http://www.fgdc.gov/standards/projects/FGDC-standardsprojects/usng/fgdc_std_011_2001_usng.pdf [accessed Mar. 25, 2011].

GeoAPI 3.0 Standard. GeoAPI Standard Working Group. Available via: http://www.geoapi.org/charter.html [accessed Mar. 25, 2011].

GIS Data Depot. GeoCommunity. Available via: http://data.geocomm.com/ [accessed Nov. 17, 2010]

The Geospatial Multi-Agency Coordination Group or GeoMAC. U.S.

Geological Survey. Available via: http://www.geomac.gov/index.html [accessed Nov. 17, 2010]

GeoTIFF FAQ. Available via: http://www.remotesensing.org/geotiff/faq.html [accessed Mar. 25, 2011].

Holtermann, K., 2010. Exercise Modeling \& Simulation Briefing. March 4. Available via: http://info.publicintelligence.net/FEMAexercisesimulation.pdf [accessed Nov. 22, 2010]

History of Hydra/Minerva. Hydra/Minerva User Group. Available via: http://www.hydra-minerva.com/history/history.htm [accessed Nov. 21, 2010]. IEEE 1512 Standards. IEEE. Available via: http://grouper.ieee.org/groups/scc32/imwg/index.html [accessed Nov. 17, 2010] IEEE Standard for Modeling and Simulation (M\&S) High Level Architecture (HLA). IEEEXplore. Available via:

http://ieeexplore.ieee.org/xpl/freeabs_all.jsp?arnumber=803526 [accessed Mar. 28, 2011].

IEEE 1278.2 Standard for Distributed Interactive Simulation - Communication Services and Profiles. IHS. Available via:

http://electronics.ihs.com/document/abstract/ZEVZCBAAAAAAAAAA [accessed Jan. 28, 2011].

InciWeb - Incident Information System. Inciweb.org. Available via: http://www.inciweb.org/ [accessed Nov. 17, 2010]

International Council on Systems Engineering. INCOSE-TD-2007-003-01:

Survey of Model-Based Systems Engineering (MBSE) Methodologies. Seattle, WA 98133. 10 June 2008. 
[ISO 2011b]

[ISU 2010]

[Jain 2011]

[Janes 2007]

[Linebarger 2007]

[LLNL 2010]

[Martin 1996]

[Massaguer 2006]

[McGrath 2006]

[NFPA 2010]

[NIEM 2011]

[NIJ 2002]

[NIMCS 2010a]

[NIMCS 2010b]
ISO Standards. ISO. Available via: http://www.iso.org/iso/iso_catalogue.htm [accessed Mar. 25, 2011].

Play2Train where people learn to play. Institute of Rural Health, Idaho State University. Available via: http://play2train.org [accessed Nov. 21, 2010] Jain, S., and C.R. McLean. 2011. Best Practices for Modeling, Simulation and Analysis (MS\&A) for Homeland Security Applications. National Institute of Standards and Technology. NIST Interagency/Internal Report (NISTIR) 7655. Janes, M. 2007. Ground Truth real-time-strategy game is serious business for Sandia software engineer. Sandia Lab News, August 17, 2007. Available via: http://www.sandia.gov/LabNews/070817.html [accessed Nov. 22, 2010] Linebarger, J.M., M.E. Goldsby, D. Fellig, M.F. Hawley, P.C. Moore, and T.J. Sa, 2007. Smallpox Over San Diego: Joint Real-Time Federations of Distributed Simulations and Simulation Users under a Common Scenario. 21st International Workshop on Principles of Advanced and Distributed Simulation (PADS'07). IEEE Computer Society. Available via:

http://www.sandia.gov/nisac/docs/Smallpox\%20over\%20San\%20Diego.pdf [accessed July 19, 2010]

Incident Command Analytic Training System (ICATS): A Simulation Approach to Training Incident Managers. Systems and Decision Sciences Technology. Lawrence Livermore National Laboratory. Available via:

https://www-eng.llnl.gov/sys_dec/sys_dec_training.html [accessed July 19, 2010].

Martin, James N., Systems Engineering Guidebook: A Process for Developing Systems and Products, CRC Press, Inc.: Boca Raton, FL, 1996.

Massaguer, D., V. Balasubramanian, S. Mehrotra, and N. Venkatasubramanian, 2006. Synthetic Humans in Emergency Response Drills. In Proceedings of Fifth International Joint Conference on Autonomous Agents and Multiagent Systems (AAMAS’06), May 8-12, 2006, Hakodate, Hokkaido, Japan. Pages 1469-1470. Association for Computing Machinery (ACM), New York, NY.

McGrath, D., D. Hill, and A. Hunt, "IC2020: Embedded Simulation for Next Generation Incident Command Software", Proceedings of the 2006 Huntsville Simulation Conference, Huntsville, AL, 18-19 October 2006. Available on-line via: http://www.ists.dartmouth.edu/library/211.pdf [accessed July 19, 2010]. Codes and Standards. National Fire Protection Association. Available via: http://www.nfpa.org/ [accessed Nov. 17, 2010]

National Information Exchange Model (NIEM). NIEM.gov. Available via: http://www.niem.gov/ [accessed Jan. 24, 2011]. Crisis Information Management Software (CIMS) Feature Comparison Report. National Institute of Justice. Available on-line via: http://www.ncjrs.gov/pdffiles1/nij/197065.pdf. [accessed July 21, 2010] Incident Command System Model Procedures Guide for Incidents Involving Structural Fire Fighting, High Rise, Multi Casualty, Highway, and Managing Large-Scale Incidents Using NIMS-ICS: Book 1. National Incident Management System Consortium (NIMCS). Available via: http://www.imsconsortium.org/NIMSBook1.htm [accessed Nov. 17, 2010]

Special Operations - Incidents Involving Hazardous Materials/WMD, Structural Collapse, Wildland, and Managing Large-Scale Incidents Using NIMS-ICS:

Book 2. National Incident Management System Consortium (NIMCS). Available via: http://www.ims-consortium.org/NIMSBook2.htm [accessed Nov. $17,2010]$ 
[NISAC 2010]

[NOAA 2010]

[NRC 2010]

[NYU 2009]

[OASIS 2010a]

[OASIS 2010b]

[OASIS 2011a]

[OASIS 2011b]

[OGC 2010]

[OGC 2011a]

[OGC 2011c]

[OJP 2010]

[OMG 2011]

[ORNL 2010a]

[ORNL 2010b]

[Pittman 2010]

[Previstar 2008]

[RAND 2010a]
National Infrastructure Simulation and Analysis Center. Sandia National Laboratories. Available via:

http://www.sandia.gov/mission/homeland/programs/critical/nisac.html [accessed November 15, 2010]

Storm Prediction Center. National Weather Service (NWS), National Oceanic and Atmospheric Administration (NOAA). Available via:

http://www.spc.noaa.gov/products/ [accessed Nov. 17, 2010]

NRC Freedom of Information Act (FOIA) Data. National Response Center (NRC). Available via: http://www.nrc.uscg.mil/foia.html [accessed Nov. 17, 2010]

Planning with Large Agent-Networks against Catastrophes (PLAN C). Center for Catastrophe Preparedness \& Response, New York University. Available via: http://www.nyu.edu/ccpr/laser/plancinfo.html [accessed Nov. 21, 2010]

Application Security Standards. Organization for the Advancement of Structured Information Standards (OASIS). Available via:

http://xml.coverpages.org/appSecurity.html [accessed Nov. 17, 2010]

XML and Emergency Management. Organization for the Advancement of Structured Information Standards (OASIS). Available via:

http://xml.coverpages.org/emergencyManagement.html [accessed Nov. 17, 2010]

Common Alert Protocol (CAP). Organization for the Advancement of Structured Information Standards (OASIS). Available via: http://www.oasisemergency.org/cap [accessed Jan. 15, 2011].

Emergency Data Exchange Language (EDXL). Organization for the Advancement of Structured Information Standards (OASIS). Available via: http://xml.coverpages.org/edxl.html [accessed Mar. 25, 2011].

Critical Infrastructure Protection Initiative. Open Geospatial Consortium (OGC). Available via: http://www.opengeospatial.org/projects/initiatives/cipi1.2 [accessed Nov. 17, 2010]

CityGML: OpenGIS City Geography Markup Language Encoding Standard. Open Geospatial Consortium, Inc. (OGC). Available via: http://www.opengeospatial.org/standards/citygml [accessed Jan. 15, 2011]. Simple Feature Access. Open Geospatial Consortium, Inc. (OGC). Available via: http://www.opengeospatial.org/standards/sfa [accessed Mar. 25, 2011]. The Global Justice XML Data Model (Global JXDM). U.S. Department of Justice. Available via: http://it.ojp.gov/jxdm/ [accessed Nov. 17, 2010] OMG Systems Modeling Language (SysML). Object Management Group, Inc. (OMG). Available via: http://omgsysml.org/ [accessed Mar. 25, 2011]. Oak Ridge Evacuation Modeling System. Oak Ridge National Laboratory. Available via: http://emc.ornl.gov/CSEPPweb/CSEPPOREMS.html [accessed Nov. 22, 2010]

VISAC Visual Interactive Site Analysis Code. Oak Ridge National Laboratory. Available via: http://visac.ornl.gov/ [accessed Nov. 21, 2010]

Pittman, E. 2010. L.A. Police Department's Hydra System Promotes Training for Command-Level Officers. Emergency Management. September 14, 2010.

Available via: http://www.emergencymgmt.com/training/LA-PoliceDepartment-Training-Hydra.html [accessed November 21, 2010] Previstar Continual Preparedness System. Previstar, Inc. Available via: http://www.previstar.com/Solutions/solutions_em.asp [accessed Nov. 21, 2010] Database of Worldwide Terrorism Incidents. RAND Corporation. Available via: http://www.rand.org/nsrd/projects/terrorism-incidents/about/scope.html 
[RAND 2010b]

[RKB 2010]

[RSSBOARD 2010]

[Saeger 2007]

[START 2010]

[TEEX 2010]

[TNRIS 2010]

[U.S. Army 2007]

[UICDS 2010]

[USDA 2010]

[USFA 2010a]

[USFA 2010b]

[USFA 2010c]

[USGS 2010]

[Wall 2009]

[Wang 2008] [accessed Nov. 17, 2010]

Public Health Systems and Preparedness. RAND Corporation. Available via: http://www.rand.org/health/centers/preparedness.html [accessed Nov. 17, 2010] Responder Knowledge Base (RKB). The Federal Emergency management Agency (FEMA). Available via: https://www.rkb.us/ [accessed Nov. 17, 2010] RSS Specification, Tutorials, Discussion. Really Simple Syndication (RSS) Advisory Board. Available via: http://www.rssboard.org/rss-specification [accessed Nov. 17, 2010]

Saeger, K., J. Ambrosiano, R.M. Roberts, and T. Cleland, 2007. CrowdSim: An Agent-based Framework for Simulating Large-crowd Dynamics. 2007 Risk Symposium, March 26-28 2007, Santa Fe, New Mexico.

Global Terrorism Database (GTD). National Consortium for the Study of Terrorism and Responses to Terrorism (START). Available via:

http://www.start.umd.edu/gtd/ [accessed Nov. 17, 2010]

Emergency Operations Training Center. Texas Engineering Extension Service. Available via:

http://www.teex.com/teex.cfm?pageid=NERRTCprog\&area=NERRTC\&templat eid=1800 [accessed Nov. 21, 2010]

Texas Natural Resources Information System (TNRIS). Texas Water Development Board. Available via: http://www.tnris.state.tx.us/DataCatalog/Index.aspx [accessed Nov. 17, 2010]

Secret Service Training Environments. America's Army Information Site. U.S. Army. Available via: http://info.americasarmy.com/projects.php?id=5 [accessed Nov. 22, 2010]

Unified Incident Command and Decision Support (UICDS) . Department of Homeland Security. Available via:

http://www.uicds.us/files/UICDS\%20in\%20Brief\%20Gov.pdf [accessed Nov. 17, 2010]

USDA Forest Service Moderate Resolution Imaging Spectroradiometer (MODIS) Active Fire Mapping Program. U.S. Department of Agriculture. Available via: ttp://activefiremaps.fs.fed.us/faq.php [accessed Nov. 17, 2010] National Fire Department Census Database. U.S. Fire Administration, Federal Emergency Management Agency, U.S. Department of Homeland Security. Available via: http://www.usfa.dhs.gov/applications/census/ [accessed Nov. 17, 2010]

National Fire Incident Reporting System. U.S. Fire Administration, Federal Emergency Management Agency, U.S. Department of Homeland Security. Available via: http://nfirs.fema.gov/?eventsDate=2009-09 [accessed Nov. 22, 2010]

Simulation Laboratory. U.S. Fire Administration, Federal Emergency Management Agency, U.S. Department of Homeland Security. Available via: http://www.usfa.dhs.gov/fireservice/subjects/incident/simlab.shtm [accessed Nov. 22, 2010]

Earthquake Hazards Program. U.S. Geological Survey. Available via: http://earthquake.usgs.gov/earthquakes/catalogs/ [accessed Nov. 17, 2010] Wall, J. 2009. Panel: Regional Initiatives in Modeling \& Simulation: Southwest \& Midwest. 2009 Modeling \& Simulation Leadership Summit. National Defense Industrial Association. Available via:

http://proceedings.ndia.org/91C0/Panel3/4_Wall.ppt [accessed Nov. 21, 2010]

Wang, J., D. Rosca, W. Tepfenhart, A. Milewski, and M. Stoute, 2008.

Dynamic Workflow Modeling and Analysis in Incident Command Systems. 
IEEE Transactions on Systems, Man and Cybernetics, Part A: Systems and Humans. Vol. 38 Issue 5, pages 1041 - 1055.

[WISER 2010] Wireless Information System for Emergency Responders (WISER). U.S. National Library of Medicine (NLM). Available via: http://wiser.nlm.nih.gov/ [accessed Nov. 17, 2010]

[WMO 2010a] A Guide to the Code Form FM 92-IX Ext. GRIB. World Health Organization. Available via: http://www.wmo.int/pages/prog/www/WDM/Guides/Guidebinary-2.html [accessed Nov. 3, 2010]. 